\title{
片流れ配置された座屈拘束ブレース機構安定条件の要因分析 OUT-OF-PLANE STABILITY FACTORS FOR DIAGONALLY INSTALLED BUCKLING RESTRAINED BRACES
}

\author{
小㠃均*1, 小西克尚*2, 松井良太*3, 竹内 徹*4 \\ Hitoshi OZAKI, Yoshinao KONISHI, Ryota MATSUI \\ and Toru TAKEUCHI
}

\begin{abstract}
Buckling restrained braces (BRBs) are widely used in seismic regions as ductile seismic-resistant and energy dissipating structural members. On the other hand, the risk of overall flexural buckling under cyclic axial loading with initial out-of-plane drifts simulating the bi-directional effects of a ground motion has been pointed out. In this regard, series of formula for securing the BRB out-of-plane stability has been proposed in previous studies. However, the actual ranges of each index that make up this series of formula are not clear for practical engineers. In this paper, these index values are clarified by carrying out the research studies of various BRBs and their connections that have been used in actual design. Based on these results, a simple method that can evaluate the out-of-plane stability condition of BRBs with various connection conditions is proposed.
\end{abstract}

Keywords: Buckling restrained brace, Connections, Buckling, Stability condition 座屈拘束ブレース，接合部，座屈，安定条件

\section{1. 序}

座屈拘束ブレース(以降 BRB)は, 履歴型のエネルギー吸収部材と して高層・中低層の新築建物から既存建物の耐震補強まで広く採用 されているが, 地震時の層間変形により $\mathrm{BRB}$ に構面外の強制変形が 生じた場合, 接合部を含む全体座屈が生じる危険性が指摘されてい

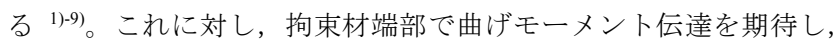
接合部と拘束材の連成系に対寸る安定条件について研究 ${ }^{10)-12) か ゙ な ~}$ されており，次の機構安定条件式が提案されている ${ }^{13)-15) 。 ~}$

$$
M_{p}^{r}-M_{0}^{r} \geq \frac{a_{r}}{1-N_{c u} / N_{c r}^{B}}\left(N_{c u}-N_{c r}^{r}\right)
$$

ここに, $M_{p}{ }^{r}$ : 拘束材端部曲げ耐力で芯材突出部の曲げ耐力と拘束材 端部の曲げ耐力のうち最小值, $M_{0}^{r}$ : 強制面外変形に伴う拘束材端 部の曲げモーメント, $N_{c u}$ : 設計用最大軸力 $\left(=\alpha_{d} N_{y}\right), N_{y}$ : 降伏軸力, $\alpha_{d}$ : 硬化係数, $a_{r}$ : 初期不整值, $N_{c r}{ }^{B}$ : 接合部を含めた BRB全体の弾 性座屈荷重, $N^{r}{ }^{r}$ : $M_{p}{ }^{r}=0$ のときの接合部座屈荷重であり細長比 $\lambda_{r}$ を

$$
\lambda_{r}=\frac{2 \xi L_{0}}{i_{r}} \cdot \sqrt{\frac{\xi \kappa_{R g}+24 / \pi^{2}}{(1-2 \xi)_{\xi} \kappa_{R g}}},{ }_{\xi} \kappa_{R g}=K_{R g} \frac{\xi L_{0}}{\gamma E I}
$$

とし，日本建築学会鋼構造設計規準式 ${ }^{16)}$ より求めることとしている。 $i_{r}, \xi, \gamma E I, K_{R g}$ は各々接合部の断面二次半径, 接合部長さ比, 接合 部の曲げ剛性，接合部の回転剛性である。

しかしながら, 機構安定条件式(1)は図 1 に示すように数多くの BRB の特性值を変数としており, 設計者はどの特性值をどの程度変
更すれば式(1)を満足させられるかを理解しないまま, 試行錯誤しな がら BRB の機構安定性を満足させなければならず,多くの検討時間 を要する問題がある。また，現実の設計において BRB がどのような 特性値の範囲で設定されているかという情報も得られていない。そ こで本論文では, 過去の実績に基づき BRB の主要な特性值の設定可 能範囲を明示寸るとともに, これらと安定条件との関係を BRB の容 量に依らない一般的な形式で図として表現し, 主要な特性值がどの 程度安定性に寄与しているかを視覚的に把握できるようにすること でBRBの機構安定条件を容易に評価できる方法を提案する。そのた めまず, 式(1)の $M_{0}^{r}$ を右辺に移項して両辺を芯材降伏軸力 $N_{y}$ で除し た式(4)の形としブレース容量に依存しない式で考える。 設計用曲げモーメント $M^{r} / N_{y}$

$M_{p}^{r} / N_{y} \geq \frac{a_{r}}{1-N_{c u} / N_{c r}^{B}}\left(\alpha_{d}-N_{c r}^{r} / N_{y}\right)+M_{0}^{r} / N_{y}\left(=M^{r} / N_{y}\right)$

軸力による偏心曲げ $M^{r}{ }_{e c} / N_{y}$ 強制変形による付加曲げ $M^{r}{ }_{0} / N_{y}$

式(4)の右辺は単位降伏軸力あたりの芯材突出部(図 1 参照)に生じ る曲げモーメント $M^{r} / N_{y}$ であり, 第 1 項が軸力による偏心曲げモー メント $M^{r}{ }_{e d} / N_{y}$ を, 第 2 項が強制面外変形に伴う付加曲げモーメント $M^{r} / N_{y}$ を示している。

次に, BRB の特性值を無次元化し, 機構安定性への感度が高いも の, もしくは設計時に数值を調整しやすいものを 4 つ選定する。こ れを「設計変数特性值」と呼ぶこととし, これらが式(4)の各項に与 える影響を図示し，どの項に対して感度が高いかを示す。 $\begin{array}{ll}* 1 & \text { (株)日建ハウジングシステム 修士 (工学) } \\ * 2 & \text { 新日鉄住金エンジニアリング 博士 (工学) } \\ * 3 & \text { 東京工業大学建築学専攻 助教・博士 (工学) } \\ * 4 & \text { 東京工業大学建築学専攻 教授・博士 (工学) }\end{array}$
Nikken Housing System Ltd., M. Eng.

Nippon Steel \& Sumikin Engineering Co., Ltd., Dr. Eng.

Assist. Prof., Dept. of Arch. and Build. Eng., Tokyo Institute of Technology, Dr. Eng.

Prof., Dept. of Arch. and Build. Eng., Tokyo Institute of Technology, Dr. Eng. 
最後に, 設計変数特性值が機構安定条件に与える影響を図示し, これを面外座屈安定性能曲線と呼ぶことと寸る。設計者が設計変数 特性值を変動させる影響を図上にて理解しながら, 機構安定条件を 満足する設計変数特性值を選定できる設計法を提案する。

一方, 機構安定性への感度が低く, 典型的な BRB においてある程 度狭い範囲に分布する特性值は, 簡略化のため一定值として取り扱 い, これを「評価用特性值」と呼ぶこととする。評価用特性值は対 象とする BRB の標準部材表を決定し, 特性值を無限化して数值のば らつきを分析し, 安全側に評価できる数值を決定する。また, 評価 用特性值を代表值とした場合, 式(4)の各項をどの程度の精度で評価 できるかについて分析する。

尚, 本研究ではモルタル充填型で座屈補剛は円形鋼管, 芯材形状 は十のものを標準部材として各種特性值の検討を行うが, 芯材形状 がーのもの，あるいは，他の座屈補剛形式のものであっても同様の 手順で, 設計変数特性值と機構安定性の関係を図示することが可能 である。本研究の検討条件は次の通りとする。(1)BRB は片流れ配置 とし, 接合部の剛性および長さは両端で概ね等しいものとする。(2) 設計用最大軸力の降伏軸力に対する比率は $\alpha_{d}=1.3$ とする。(3)BRB の 芯材材質は LYP225 とする。(4)接合部は弾性範囲とする。

\section{BRB の特性值}

$\mathrm{BRB}$ 各部位の寸法と剛性の符号を図 1 に示寸。BRB 全長を $L_{0}$, 接合部長さを $\xi L_{0}$, 芯材の塑性化させる部位の幅を $W_{0}$, 拘束材端部の 拡幅させた幅を $W_{1}$ とし, その貫入長を $L_{i n}$ とする。接合部のボルト 接合する部位の幅を $W_{2}$ とし, 幅 $W_{0}, W_{1}, W_{2}$ の各部位の断面積を $A_{0}, A_{1}, A_{2}$ とする。 $A_{2}$ にはスプライスプレートの断面積は含めず, ボルト孔欠損は考慮しない。拘束鋼管の曲げ岡性を $E I$ とし，接合部 (弾性部)の曲げ剛性を $\gamma E I$ とする。 $\gamma E I$ の值にはスプライスプレート の断面も含むものとする。以上の寸法の定義に基づき, BRB の機構 安定性を司る各特性值を, 主要な変動パラメータとしての「設計変 数特性值」とある程度範囲が限定できる「評価用特性值」に分けて 考える。
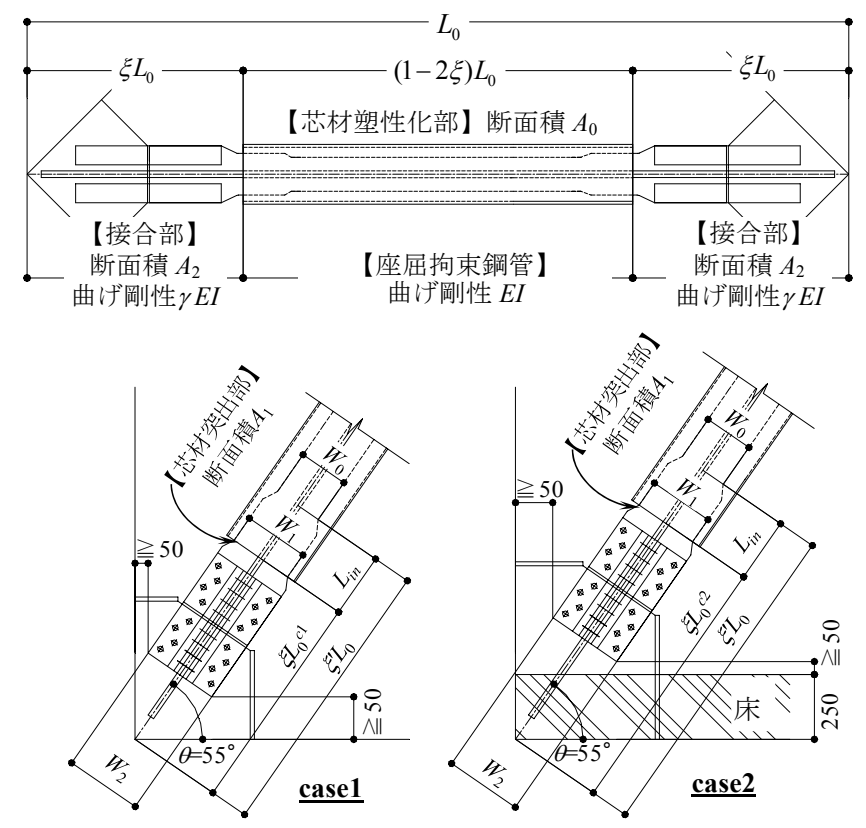

図 1 座屈拘束ブレース寸法及び剛性と納まり例

\section{1 設計変数特性值}

BRB の機構安定性への影響が特に大きい設計変数特性值として 次の 4 つを採用する。

1) 接合部長さ比 $\xi$ : 図 1 に示すようにブレース全体の長さに対す る接合部長さの比であり，既往の BRB の機構安定性に関する 研究 2-5),11-14)においても重要なパラメータとされている。

2) 座屈長さ比 $\ell_{k 0}\left(=L_{0} / L_{k}\right)$ : 全長 $L_{0}$, 曲げ剛性 $E I$, 両端ピンのオイ ラ一座屈荷重が芯材塑性化部の最大降伏軸力 $N_{y \max }\left(=\sigma_{y \max } A_{0}\right)$ の 1.5 倍となるようなブレース長さを本論文では限界座屈長さ $L_{k}\left(=\sqrt{\pi^{2} E I / 1.5 N_{y \max }}\right)$ と呼び, $L_{0}$ を限界座屈長さ $L_{k}$ で除した值 を座屈長さ比 $\ell_{k 0}$ と呼ぶこととする。座屈長さ比 $\ell_{k 0}$ は座屈拘束 鋼管剛性を示寸指標であり，設計時には座屈長さ比が 1 以下 $\left(\ell_{k 0}<1\right)$, すなわち $\mathrm{BRB}$ の有効座屈長さが，限界座屈長さ以下と なるように座屈拘束鋼管を選択する。

3) 貫入長比 $\ell_{i n}\left(=L_{\mathrm{in}} / W_{1}\right)$ : 貫入長 $L_{i n}$ は既往の研究 ${ }^{13) \sim 15)}$ に倣い $W_{1}$ との比で表現する。貫入長比は座屈拘束鋼管端部の剛性・耐力 に寄与する指標である。

4) 接合部回転ばね剛性比 $\kappa_{R g}$ : 式(3)で算出される回転剛性の比で ある。接合部の回転剛性については 3 章にて検討する。

\section{2 評価用特性值}

本研究では実際の設計で採用機会の多いモルタル充填型 BRB 部 材 ${ }^{17)}$ を対象とし, 表 1 にその標準部材表を示す。ここでは次の $5 つ$ の無次元化された特性值に注目する。

1) 接合部の曲げ剛性と座屈拘束鋼管の曲げ岡性の比 $\gamma$

2) 接合部断面積と芯材塑性化部断面積の比 $A_{2} / A_{0}$

3) 芯材突出部断面積と芯材塑性化部断面積の比 $A_{1} / A_{0}$

4) 座屈拘束鋼管端部の無次元化回転ば釉剛性比 ${ }_{L} \kappa_{R r}\left(=K_{R r} \times L_{k} / E I\right)$

5) 芯材突出部幅に対する限界座屈長さの比 $\ell_{w k}\left(=L_{k} / W_{1}\right)$

ここで, 標準部材の接合部は降伏軸力 $N_{y}\left(=\sigma_{y} A_{0}\right)$ の 1.3 倍に対して 短期許容応力度以下となるように設計されており, $A_{2} / A_{0}$ は若干のば らつきがあるものの $1.57 \sim 1.75$ の範囲に分布する。また，標準部材 の芯材突出部は, 塑性化部断面積の 1.3 倍以上となるように設計さ れている。 ${ }_{L} K_{R r}$ は文献 12$)$ の方法により算出した拘束材端部の回転剛 性 $K_{R r}$ を, 座屈拘束鋼管の曲げ剛性と限界座屈長さの比 $E I / L_{k}$ で無次 元化したものである。 $\ell_{w k}$ は貫入長比と合わせて検討する指標であり, $\ell_{w k}$ が大きいほど初期不整に伴う拘束材端部の面外変位が大きくな る(5 章参照)。一方， $\ell_{w k}$ が大きいほど面外変形に伴う付加曲げモー メントは小さくなる(7 章参照)。

標準部材における上記 5 つの無次元化された特性值の分布を図 2 に示す。本研究では, より機構安定性一影響の大きい特性值に注目 するため, ある程度狭い範囲に分布する特性值は評価用特性值とし て一定值とする。軸力による偏心曲げモーメントを算出する場合に は, 剛性は低いほうが安全側の評価となり, 逆に付加曲げモーメン 卜を算出する場合には，剛性は高い方が安全側の評価となる。この ように, 無次元化された特性值のうち機構安定性の検証が安全側と なるように，表 2 に示寸評価用特性值の数值を設定する。尚，拘束 材端部回転バネ剛性比 ${ }_{L} \kappa_{R r}$ の評価式 $\left.{ }^{12}\right)$ は, 拘束材幅や板厚, 芯材突 出部の幅等が変数であるが, 貫入長比 $\ell_{i n}$ が最も支配的な変数であり 拘束材端部回転バネ剛性比 ${ }_{L} \kappa_{R r}$ の評価用特性值は, 貫入長比 $\ell_{i n}$ ごと に設定した。 
表 1 座屈拘束ブレース LYP225 芯材形状+タイプの標準部材表

\begin{tabular}{|c|c|c|c|c|c|c|c|c|c|c|c|c|c|c|c|c|}
\hline & \multicolumn{8}{|c|}{ 芯材(LYP225) } & \multicolumn{2}{|c|}{ 降伏軸力 } & \multirow[b]{2}{*}{$\begin{array}{c}\text { 補剛管 } \\
\text { (STK400) }\end{array}$} & \multicolumn{2}{|c|}{ 剛性 } & \multirow[b]{2}{*}{$\begin{array}{c}\text { 限界座屈 } \\
\text { 長さ } \\
L_{k}[\mathrm{~mm}]\end{array}$} & \multicolumn{2}{|c|}{ 接合部長さの代表例 } \\
\hline 部材符号 & $\begin{array}{l}\text { 形 } \\
\text { 状 }\end{array}$ & $\begin{array}{c}\text { 塑性 } \\
\text { 化部 } \\
\text { 断面積 } \\
A_{0}\left[\mathrm{~mm}^{2}\right] \\
\end{array}$ & $\begin{array}{l}\text { 拡幅部 } \\
\text { 断面積 } \\
A_{1}\left[\mathrm{~mm}^{2}\right]\end{array}$ & \begin{tabular}{|l|} 
接合部 \\
断面積 \\
$A_{2}\left[\mathrm{~mm}^{2}\right]$ \\
\end{tabular} & \begin{tabular}{|c|} 
板厚 \\
$t$ \\
{$[\mathrm{~mm}]$} \\
\end{tabular} & $\begin{array}{c}\text { 塑性化 } \\
\text { 部幅 } \\
W_{0}[\mathrm{~mm}]\end{array}$ & $\begin{array}{c}\text { 突出 } \\
\text { 部幅 } \\
W_{1}[\mathrm{~mm}]\end{array}$ & $\begin{array}{c}\begin{array}{c}\text { 弹性 } \\
\text { 部幅 } \\
W_{2}[\mathrm{~mm}]\end{array} \\
\end{array}$ & $\begin{array}{c}\text { 平均值 } \\
225 \times A_{0} \\
N_{y}[\mathrm{kN}] \\
\end{array}$ & \begin{tabular}{|c|} 
最大值 \\
$245 \times A_{0}$ \\
$N_{y \max }[\mathrm{kN}]$ \\
\end{tabular} & & $\begin{array}{c}\text { 補剛材 } \\
\text { 曲げ岡性 } \\
E I\left[\mathrm{Nmm}^{2}\right]\end{array}$ & \begin{tabular}{|c|} 
接合部 \\
曲げ剛性 \\
$\gamma E I\left[\mathrm{Nmm}^{2}\right]$
\end{tabular} & & $\begin{array}{c}\text { case } 1 \\
\xi L_{0}{ }^{c 1}[\mathrm{~mm}]\end{array}$ & $\begin{array}{c}\text { case2 } \\
\xi L_{0}{ }^{c 2}[\mathrm{~mm}]\end{array}$ \\
\hline UB225-150+ & $+\frac{1}{+1}$ & 8675 & 8925 & 11675 & 25 & 146 & 191 & 246 & 1502 & 1635 & $\overline{\mid \phi-267.4 \times 6.0}$ & 3444 & 3677 & 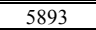 & 990 & 1226 \\
\hline UB225-175+ & + & 7784 & 10360 & 12992 & 28 & 153 & 199 & 246 & 1751 & 1907 & $\phi-267.4 \times 6.0$ & 3444 & 4213 & 5457 & 1145 & 1381 \\
\hline UB225-200+ & + & 8925 & 11825 & 14175 & 25 & 191 & 249 & 296 & 2008 & 2187 & $\phi-318.5 \times 6.0$ & 8632 & 6820 & 6661 & 817 & 1040 \\
\hline UB225-225+ & + & 10024 & 13384 & 15960 & 28 & 193 & 253 & 299 & 2255 & 2456 & $\phi-318.5 \times 6.0$ & 8632 & 9229 & 6285 & 914 & 1136 \\
\hline UB225-250+ & + & 11088 & 14784 & 17528 & 28 & 212 & 278 & 327 & 2495 & 2717 & $\phi-355.6 \times 6.4$ & 8632 & 13840 & 7291 & 937 & 1152 \\
\hline UB225-300+ & + & 13320 & 17784 & 22680 & 36 & 203 & 265 & 333 & 2997 & 3263 & $\phi-355.6 \times 6.4$ & 14746 & 19928 & 6652 & 1056 & 1270 \\
\hline UB225-350+ & + & 15480 & 20592 & 24552 & 36 & 233 & 304 & 359 & 3483 & 3793 & $\phi-406.4 \times 6.4$ & 21946 & 30245 & 7564 & 1162 & 1370 \\
\hline UB225-400+ & + & 17760 & 23680 & 28480 & 40 & 242 & 316 & 376 & 3996 & 4351 & $\phi-406.4 \times 6.4$ & 21946 & 33103 & 7062 & 1278 & 1481 \\
\hline UB225-450+ & + & 20000 & 26640 & 31440 & 40 & 270 & 353 & 413 & 4500 & 4900 & $\phi-457.2 \times 7.9$ & 21946 & 37268 & 8802 & 1402 & 1596 \\
\hline
\end{tabular}

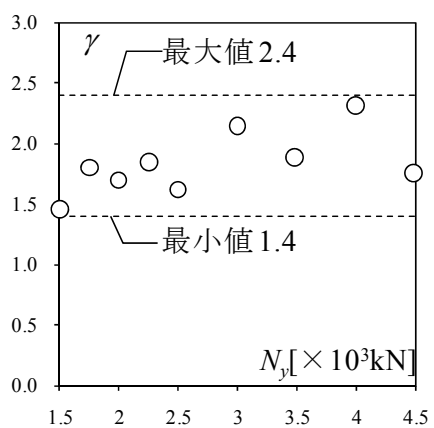

1)接合部曲げ岡性比 $\gamma$

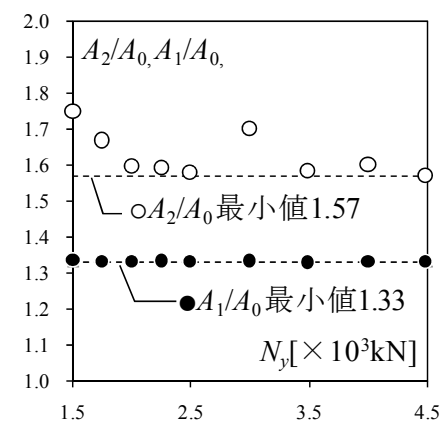

2)断面積比 $A_{2} / A_{0}, A_{1} / A_{0}$

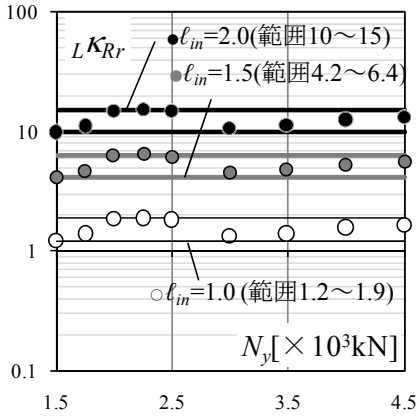

3)拘束材端部回転バネ剛性比 ${ }_{L} \kappa_{R r}$

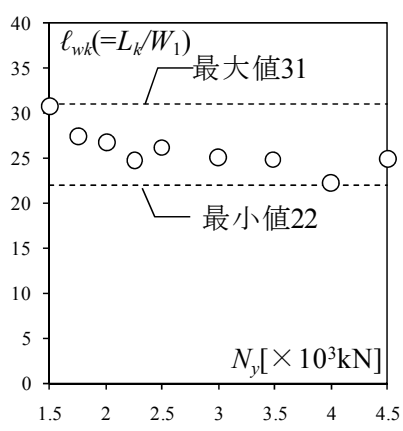

4)芯材突出部幅比 $\ell_{w k}$

図 2 標準部材の評価用特性値の分布

表 2 設定した評価用特性値

\begin{tabular}{|c|c|c|c|c|c|c|}
\hline \multicolumn{2}{|c|}{ 無次元化された特性值 } & 分布範囲 & $\begin{array}{c}\text { 軸力による } \\
\text { 偏心曲げ } \\
M_{e c}^{r} / N_{y} \\
\end{array}$ & \begin{tabular}{|c|} 
強制変形 \\
による付加曲げ \\
$M_{0}^{r} / N_{y}$ \\
\end{tabular} & $\begin{array}{c}\text { 芯材突出部の } \\
\text { 曲げ而力 } \\
M_{p}^{r} / N_{y} \\
\end{array}$ & $\begin{array}{l}\text { 適用章, } \\
\text { 節番号 }\end{array}$ \\
\hline \multicolumn{2}{|c|}{ 接合部曲げ岡性比 $\gamma$} & $1.4 \sim 2.4$ & 1.4 & 2.4 & - & $4.2,7$ \\
\hline \multicolumn{2}{|c|}{ 接合部断面積比 $A_{2} / A_{0}$} & $1.57 \sim$ & 1.57 & - & - & 6.2 \\
\hline \multicolumn{2}{|c|}{ 芯材突出部断面積比 $A_{1} / A_{0}$} & $1.33 \sim$ & - & - & 1.33 & 8.2 \\
\hline \multirow{3}{*}{$\begin{array}{l}\text { 座屈拘束鋼管端部 } \\
\text { 回転ばね剛性比 }{ }_{L} \kappa_{R r}\end{array}$} & $\ell_{\text {in }}\left(=L_{\text {in }} / W_{1}\right)=1.0$ の場合 & $1.2 \sim 1.9$ & 1.2 & 1.9 & - & \multirow{3}{*}{$4.2,7$} \\
\hline & $\ell_{\text {in }}\left(=L_{\text {in }} / W_{1}\right)=1.5$ の場合 & $4.2 \sim 6.4$ & 4.2 & 6.4 & - & \\
\hline & $\ell_{\text {in }}\left(=L_{\text {in }} / W_{1}\right)=2.0$ の場合 & $10 \sim 15$ & 10 & 15 & - & \\
\hline \multicolumn{2}{|c|}{ 芯材突出部幅比 $\ell_{w k}\left(=L_{\mathrm{k}} / W_{1}\right)$} & $22 \sim 31$ & 31 & 22 & - & $5.1,7$ \\
\hline
\end{tabular}

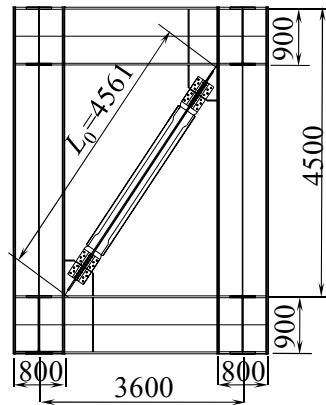

図 3 BRB の片流れ配置例

\section{3. 設計変数特性值の検討範囲}

\section{1 BRB 本体に関する設計変数特性值の検討範囲}

既往の論文 ${ }^{12)}$ では貫入長比と有効座屈長さの関係を検討しており， $\ell_{i n}$ が大きいほど有効座屈長さは短くなるが，その傾向は $\ell_{i n}=2$ 程度 で頭打ちとなることが示されている。そのため, 貫入長比 $\ell_{i n}$ は 1 〜 2 を検討範囲とする。

その他の設計変数特性值の検討範囲を分析寸るために図 3 に示す ように BRB をスパン $3600 \mathrm{~mm}$, 階高 $4500 \mathrm{~mm}$, 柱幅 $800 \mathrm{~mm}$, 梁せい $900 \mathrm{~mm}$ のフレームに片流れで配置した場合を検討する。BRB を表 1 の標準部材とした場合, 図 4 に示寸ように $\ell_{k 0}$ は $0.5 \sim 0.8$ 程度に分布 するため, 本研究では $\ell_{k 0}=1.0,0.7$ を検討の対象とする。

$\mathrm{BRB}$ の接合部長さ $\xi L_{0}$ は $\mathrm{BRB}$ の角度やガセットプレートの必要溶 接長さ,ボル卜締付けの可否などで決定される。図 1 に, これまで の設計において採用機会が多い，BRB の角度が $55^{\circ}$ である場合につ いて $2 つ の$ 納まり例を示す。case1 は鉄骨柱・梁とスプライスプレー トのクリアランスを最小 $50 \mathrm{~mm}$ とする場合であり, case2 は床仕上げ を梁から $250 \mathrm{~mm}$ 上がりとし, 床仕上げからスプラスプレートのク リアランスを $50 \mathrm{~mm}$ 以上とする場合である。両 case の接合部長さ $\xi L_{0}{ }^{c 1}, \xi L_{0}{ }^{c 2}$ を表 1 に示す。 $\ell_{k 0}=1.0,0.7$ となるように BRB 全長 $L_{0}$ を

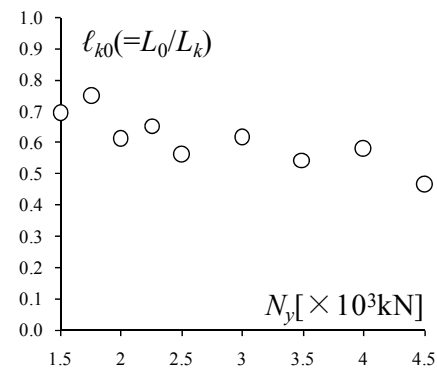

図 4 座屈長さ比 $\ell_{k 0}$ の分布

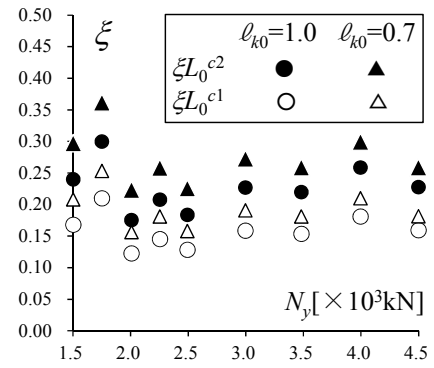

図 5 接合部長さ比 $\xi$ の分布

設定した場合，case1, case2 各々の $\xi$ の分布は図 5 に示す通り $\xi=0.10$ 〜0.36 となり, これを本研究での検討範囲とする。

\section{2 BRB の接合部回転剛性に関する設計変数特性値}

抽出された実施設計例のうち, 高さ $100 \mathrm{~m}$ クラスの超高層オフィ スビルでの標準的な柱梁寸法に対する柱梁接合部の FEM 解析を行 い, 式(3)で表される無次元化回転ばね剛性比 $\kappa_{\text {促 }}$ について評価する。 解析モデルは図 6 に示寸通り, 柱を階高の $1 / 2$, 構面内及び構面外 の梁をスパンの $1 / 2$ 分それぞれ切り出した部分と BRB 接合部とする。 各柱梁端の境界条件は, $x y z$ 変位固定, 回転自由のピン接合とする。 BRB の材質を LYP225，降伏軸力を $2000 \mathrm{kN}$ と仮定し，BRB 接合部 
先端に面外荷重 $P=100 \mathrm{kN}$ を与えて載荷点の $y$ 方向変位を算出する。

尚, 載荷点の変位には柱梁の変形が含まれるが, 柱梁フェイス交 点の $y$ 方向変位自体は載荷点変位の $1 \%$ 程度で微小である。

解析モデル一覧を表 3 に, BRB 接合部のリブ名称を図 6 に, ブレ 一ス配置を図 7 に，接合部モデル例を図 8 に示す。解析モデルとし ては, ブレース配置を 2 ケース, 梁サイズを 2 ケース設定し, 表 3 中に示すように，ガセットプレートに取り付くリブの配置を変化さ せて検討を行う。また, 比較のため図 8 の斜線部で示すガセットプ レートの柱梁との境界節点を 6 自由度固定とした場合について検討 を行う(名称 100 番台)。図 9 に解析で求めた $y$ 方向変位を示寸。図 中, 文献 5)に示される接合部剛性評価式より求めた $y$ 方向変位を示 すが, No.105〜112 の解析変位と概ね一致した。

既往の研究 ${ }^{13)}$ に倣い $y$ 方向変位を図 10 に示すように設定し, 回 転剛性 $K_{R g}$ のバネに置換する。尚, 柱梁フェイス交点の $y$ 方向変位 自体は, 載荷点変位の $1 \%$ 程度と微小なため, 回転角の原点は柱梁 フェイス交点と考える。式(5)のように回転バネを有する変位 $y_{r}$ はバ ネの回転成分 $y_{r s}$ と, 接合部の弾性変形成分 $y_{r e}$ の和である。ここで,

FEM 解析で算出した $y_{r}$ と式(6)にて算出できる接合部の変位 $y_{r s}$ を式 (7)に代入して接合部回転剛性を算出する。さらに, 式(3)にて接合部 の曲げ剛性 $\gamma E I / \xi L_{0}$ を用いて接合部回転剛性を無次元化する。

表 3 解析モデルー覧

\begin{tabular}{|c|c|c|c|c|c|c|c|}
\hline 名称 & $\begin{array}{l}\text { リブ } \\
\text { 配置 }\end{array}$ & $\begin{array}{l}\text { BRB } \\
\text { 配置 }\end{array}$ & $\begin{array}{c}\text { ブレース角度 } \\
\phi[\text { deg }\end{array}$ & $\begin{array}{l}\text { 接合部長さ } \\
\xi L_{0}[\mathrm{~mm}]\end{array}$ & $\begin{array}{l}\text { 柱サイズ } \\
\text { (SN490C) }\end{array}$ & $\begin{array}{l}\text { 梁サイズ } \\
\text { (SN490B) }\end{array}$ & $\begin{array}{c}\text { 面外梁サイズ } \\
\text { (SN490B) }\end{array}$ \\
\hline No.1 & \multirow{4}{*}{ 無 } & \multirow{2}{*}{ 短スパン } & 55.3 & 771 & \multirow{12}{*}{$\square-800 \times 800 \times 28 \times 28$} & H- $900 \times 300 \times 16 \times 28$ & H- $900 \times 400 \times 16 \times 28$ \\
\hline No. 2 & & & 54.3 & 761 & & H- $1200 \times 300 \times 19 \times 22$ & H- $1200 \times 400 \times 16 \times 28$ \\
\hline No. 3 & & \multirow{2}{*}{ 長スパン } & 32.7 & 792 & & H- $900 \times 250 \times 16 \times 19$ & H- $900 \times 250 \times 16 \times 20$ \\
\hline No. 4 & & & 30.5 & 820 & & $\mathrm{H}-1200 \times 250 \times 19 \times 19$ & $\mathrm{H}-1200 \times 250 \times 19 \times 20$ \\
\hline No.5 & \multirow{4}{*}{$\begin{array}{l}\text { リフフ } \\
(1)^{+}(2)\end{array}$} & \multirow{2}{*}{ 馧スパン } & 55.3 & 771 & & H- $900 \times 300 \times 16 \times 28$ & H- $900 \times 400 \times 16 \times 28$ \\
\hline No.6 & & & 54.3 & 761 & & H- $1200 \times 300 \times 19 \times 22$ & H- $1200 \times 400 \times 16 \times 28$ \\
\hline No.7 & & & 32.7 & 792 & & H- $900 \times 250 \times 16 \times 19$ & $\mathrm{H}-900 \times 250 \times 16 \times 20$ \\
\hline No.8 & & & 30.5 & 820 & & H- $1200 \times 250 \times 19 \times 19$ & H-1200×250×19×20 \\
\hline No.9 & \multirow{4}{*}{$\begin{array}{c}\text { リブ } \\
(1)+(2)+(3)\end{array}$} & \multirow{2}{*}{ 短スパン } & 55.3 & 771 & & $\begin{array}{l}\mathrm{H}-900 \times 300 \times 16 \times 28 \\
\end{array}$ & $\begin{array}{l}\mathrm{H}-900 \times 400 \times 16 \times 28 \\
\end{array}$ \\
\hline No.10 & & & 54.3 & 761 & & 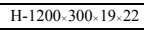 & $\mathrm{H}-1200 \times 400 \times 16 \times 28$ \\
\hline No.11 & & & 32.7 & 792 & & H- $900 \times 250 \times 16 \times 19$ & H- $900 \times 250 \times 16 \times 20$ \\
\hline No.12 & & & 30.5 & 820 & & H- $1200 \times 250 \times 19 \times 19$ & H- $1200 \times 250 \times 19 \times 20$ \\
\hline
\end{tabular}

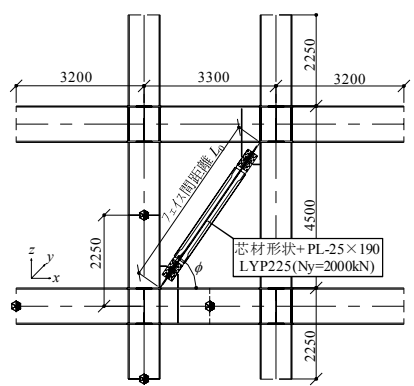

(a)短スパン型配置

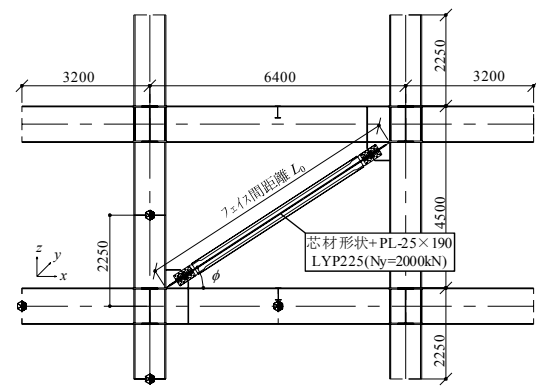

(b)長スパン型配置

図 7 ブレース配置

$$
\begin{array}{ll}
y_{r}=y_{r s}+y_{r e}, & y_{r s}=P \times\left(\xi L_{0}\right)^{3} / 3 \gamma E \\
K_{R g}=P \times \xi L_{0}{ }^{2} /\left(y_{r}-y_{r s}\right), & \xi_{R g} \kappa_{R g}=K_{R g} \times \xi L_{0} / \gamma E I
\end{array}
$$

式(3)より求めた, 接合部の無次元化回転ばね剛性比 $\xi \kappa_{R g}$ を図 11 に 示す。リブの配置による $\kappa_{R g}$ の変化が顕著に表れている。また, No.101〜112 の ${ }_{\xi} \kappa_{R g}$ は, No.1〜12 の值の 2 倍〜3 倍程度となっており, ガセットプレートの柱梁との境界節点の 6 自由度を固定とすること で $\kappa_{R g}$ を過大に評価する傾向がある。一方, No.105〜112の範囲では 文献 5)の手法で評価した $\kappa_{R g}$ と FEM 解析結果は概ね良い対応を示 している。

本研究では接合部剛性を低・中・高の 3 ケース想定し, BRB の降伏 軸力に依らず $\xi_{\xi g}=0.15,0.30,0.60$ として検討を行うが，中剛性につ いては 8 章に結果のみを示し，4 章から 7 章は低剛性および高剛性 の場合 $\left.{ }_{\xi} \kappa_{R g}=0.15,0.60\right)$ のを示すものとする。

設計変数特性值の検討範囲を表 4 にまとめて示寸。以下に設計変 数特性值が式(4)を構成する各項へ与える影響を分析していく。

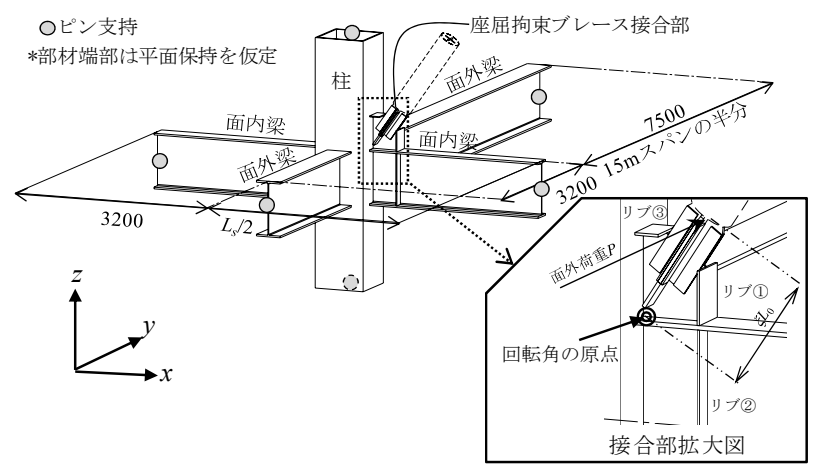

図 6 FEM 解析モデル
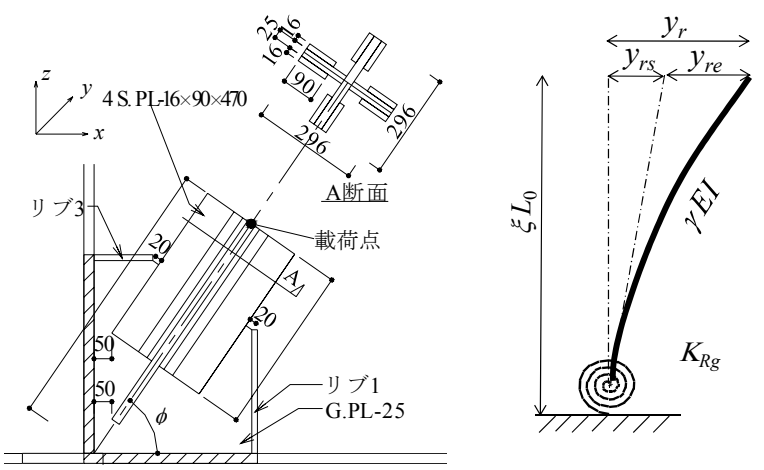

図 8 接合部モデル例

図 $10 y$ 方向変位の設定

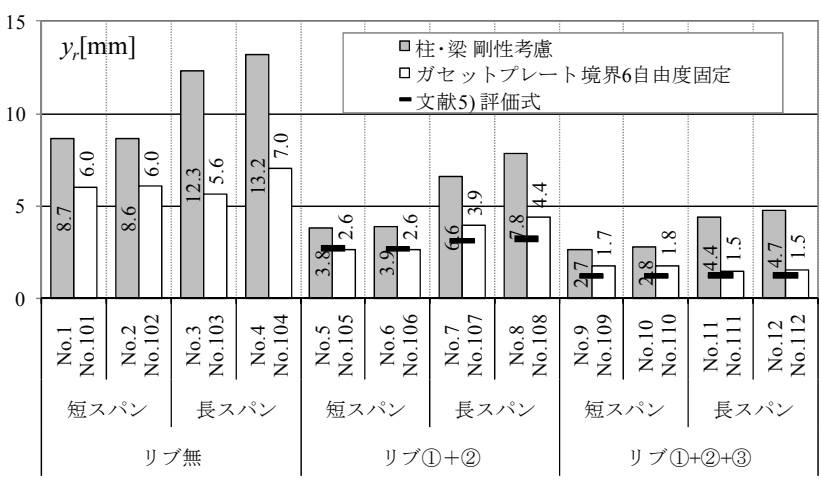

図 $9 y$ 方向変位 $y_{r}$

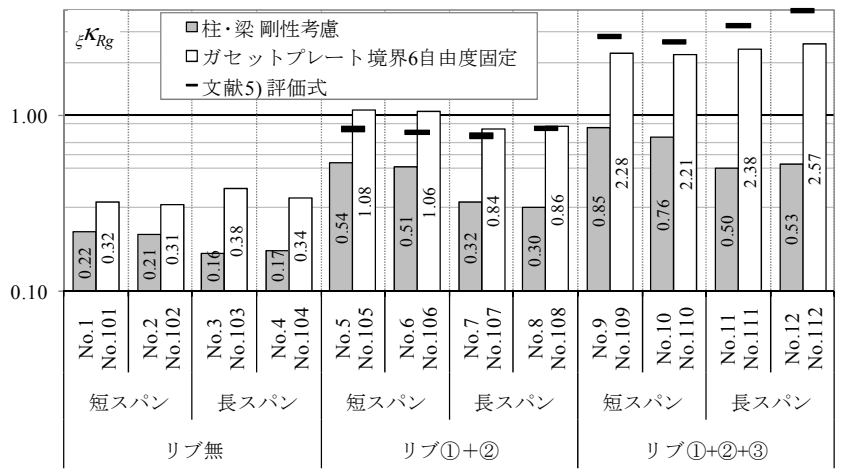

図 11 無次元化回転ばね剛性比 $\xi \kappa_{R g}$ 
表 4 設計変数特性値の検討範囲

\begin{tabular}{|c||c|}
\hline 特性値 & 検討範囲 \\
\hline$\xi K_{R g}$ & $0.15,(0.3), 0.60$ \\
\hline$\ell_{k 0}\left(=L_{0} / L_{k}\right)$ & $1.0,0.7$ \\
\hline$\xi$ & $0.10 \sim 0.36$ \\
\hline$\ell_{i n}\left(=L_{i n} / W_{1}\right)$ & $1.0,(1.5), 2.0$ \\
\hline
\end{tabular}

注）（）内の場合は 8 章に結果のみを示す。

\section{4. 弾性全体座屈荷重 $N_{c r}{ }^{B}$}

\section{1 全体座屈荷重の検討モデル}

全体座屈荷重の検討モデルを図 12 に示す。 $N_{c r}{ }^{B 0}$ は両端をピンと 仮定した座屈荷重, $N_{c r}{ }^{B s}$ は接合部端部の回転剛性 $K_{R g}$ を考慮した座屈 荷重である ${ }^{13)} 。 N_{c r}{ }^{B m 1}, N_{c r}{ }^{B m 2}$ は $K_{R g}$ に加え, 拘束材端部の回転剛性 $K_{R r}$ を考慮した対称モード/逆対称モードの座屈荷重である。 $N_{c r}{ }^{B m 1}, N_{c r}{ }^{B m 2}$ と $K_{R r}$ の算出方法は文献 12$)$ によ。また, 接合部端部回転剛性を考 慮した座屈荷重 $N_{c r}{ }^{B s}, N_{c r}{ }^{B m 1}, N_{c r}{ }^{B m 2}$ を総称して $N_{c r}{ }^{B}$ と呼ぶこととする。

\section{2 BRB 全体の座屈荷重評価}

図 13 にと $N_{c r}{ }^{B}$ を $N_{c r}{ }^{B 0}$ で除した值との関係を示す。表 2 の評価 用特性值を用いて全体座屈荷重を算出した場合と, 標準部材 (case1,case2)各々の特性值を用いて算出した場合を比較する。 $\gamma$ と ${ }_{L} \kappa_{R r}$ の評価用特性値は, 安全側の評価となるように, 表 2 に示寸分 布範囲中の最小值を採用した。評価用特性値を用いた全体座屈荷重 は標準部材の全体座屈荷重の下限值を抑えていることがわかる。ま た, 接合部が低剛性ほど, 貫入長が短いほど, 接合部長さが長いほ ど 7 要素モデルの座屈荷重は小さくなる傾向にある。特に, $N_{c r}{ }^{B m 1} / N_{c r}{ }^{B 0}<1.0$ の領域ではブレース長さが限界座屈長さ以下であっ ても座屈する危険性があることを示しており, 図 13 によりその範囲 を知ることができる。

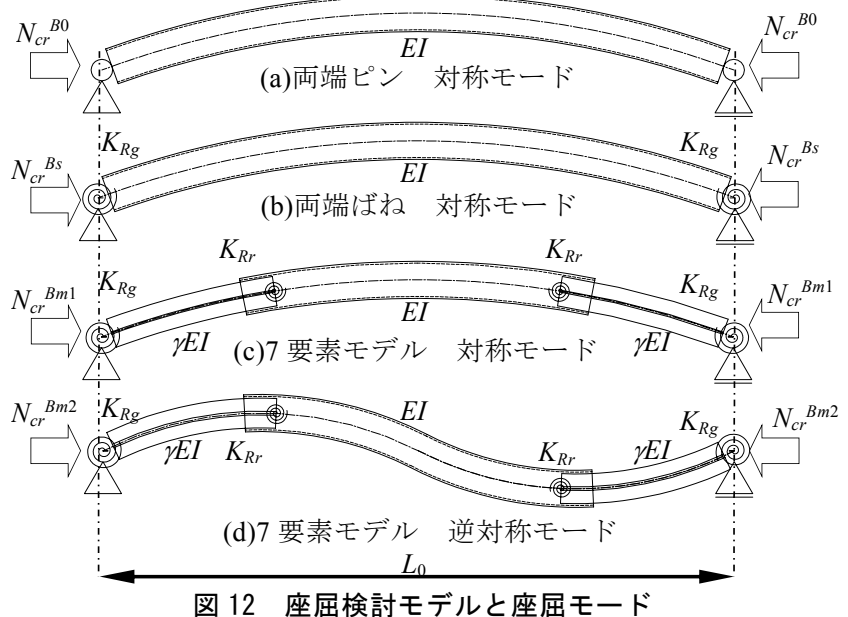

5. 設計荷重時の拘束材端部の面外変位 $a_{r} /\left(1-N_{c u} / N_{c r}^{B}\right)$

\section{1 初期不整值 $a_{r}$ の検討}

BRB 拘束材端部の初期不整值と座屈前変形による変位の増幅に ついて検討する。既往の研究 ${ }^{13)-15)}$ に示寸初期不整值 $a_{r}$ (図 14 参照) を無次元化された特性值で表現すると以下となる。

$$
a_{r}=a+e+s_{r}+2 s_{r} \frac{\xi L_{0}}{L_{i n}}=a+e+s_{r}+2 s_{r} \xi \frac{\ell_{k 0} \cdot \ell_{w k}}{\ell_{i n}}
$$

ここで, 図 14 に示すように, $e$ は加力点の偏心距離， $s_{r}$ は芯材と拘

\begin{tabular}{c|c|c|c}
$N_{c r}{ }^{B} / N_{c r}{ }^{B 0}$ 凡例 & $N_{c r}{ }^{B s} / N_{c r}{ }^{B 0}$ & $N_{c r}{ }^{B m 1} / N_{c r}{ }^{B 0}$ & $N_{c r}{ }^{B m 2} / N_{c r}{ }^{B 0}$ \\
\hline 評価用特性值を用いた座屈荷重 & ---- & - & - \\
\hline 標準部材の座屈荷重(case1, case2) & & $\bullet, \triangle$ & $0, \Delta$
\end{tabular}

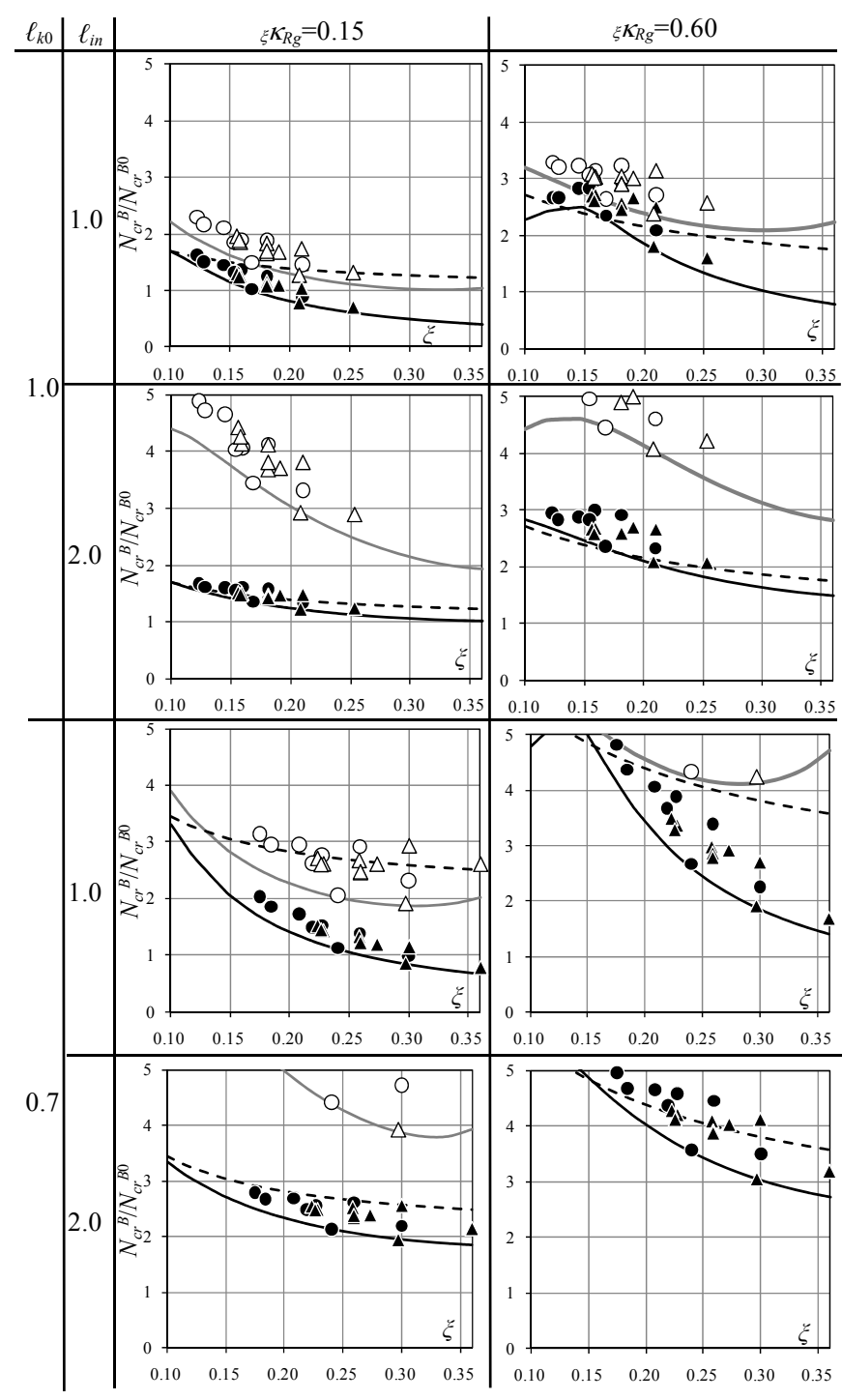

図 13 両端ピン座屈荷重に対する各モデルの弾性全体座屈荷重

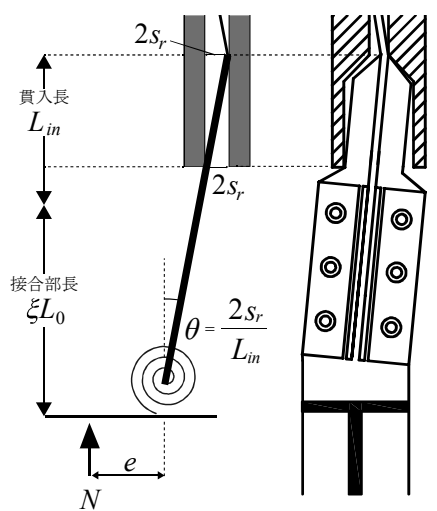

図 14 初期不整値 $a_{r}$ のモデル

束材のクリアランスである。また， $a$ は芯材の元たわみ量である。 本論文では $a+e=3 \mathrm{~mm}, s_{r}=1 \mathrm{~mm}$ と仮定した。 $\ell_{w k}$ が大きいほど初期不 
整量は大きくなるため, 表 2 で設定した評価用特性值 $\ell_{w k}$ は分布中 の最大值 31 としている。図 15 に評価用特性值を用いて算出した初 期不整值と標準部材(case1,case2)各々の特性値を用いて算出した初 期不整值を示す。評価用特性值を用いて算出した值は, 標準部材個々 の值の上限を抑えていることがわかる。

\section{2 座屈前変形による変位 $a_{r} /\left(1-N_{c u} / N_{c r}^{B}\right)$ の検討}

両端ピンのオイラー座屈荷重 $N_{c r}{ }^{B 0}$ を降伏軸力の最大值 $N_{\max }$ の 1.5 倍としていることを踏まえ, 4 章で検討した $N_{c r}{ }^{B} / N_{c r}{ }^{B 0}$ の值を使って 設計荷重時の拘束材端部の変位を表すと式(9)のようになる。ただし, $N_{c u}<N_{c r}{ }^{B}$ の場合に限る。

$$
\frac{a_{r}}{1-\frac{N_{c u}}{N_{c r}^{B}}}=\frac{a_{r}}{1-\frac{N_{c u} / N_{y}}{N_{c r}^{B} / N_{y}}}=\frac{a_{r}}{1-\frac{1.3}{1.5 \cdot 245 / 225 \cdot N_{c r}^{B} / N_{c r}^{B 0}}}
$$

設計荷重時の拘束材端部の変位を算出するために, BRB 構面と直 交方向に層間変位が生じる状況を想定する。この場合 BRB は面外方 向に逆対称の変形モードとなるため, 全体座屈荷重としては図 12(d) に示寸逆対称モード座屈荷重 $N_{c r}{ }^{B m 2}$ に注目し, 比較のため図 12(b) に示寸両端バネの対称モード座屈荷重 $N_{c r}{ }^{B s}$ についても検討する。

表 2 の評価用特性值を用いて算出した座屈前変形による変位と標 準部材(case1, case2) 各々の特性值を用いて算出した值との比較を 行う。図 16 に $\xi$ と座屈前変形による変位の関係を示す。全体座屈荷 重として $N_{c r}{ }^{B m 2}$ を用いた場合, 評価用特性值を用いた座屈前変形に よる変位は, 標準部材各々の特性值を用いた変位を包絡しているこ とがわかる。 $N_{c r}{ }^{B s}$ を用いた座屈前変形による変位は, 概ね $N_{c r}{ }^{B m 2}$ を 用いた值と同程度であるが, 本研究ではより精緻なモデルである逆 対称モード座屈荷重 $N_{c r}{ }^{B m 2}$ を用いた変位により評価する。座屈前変 形による変位量は $\xi$ が大きいほど大きくなる。また, 接合部剛性が 大きく, 貫入長比が大きいほど座屈前変形による変位量は小さくな るが，特に $\ell_{k 0}=0.7, \ell_{i n}=2.0$ では $\kappa_{\xi} \kappa_{R g}$ の大きさに依らず $a_{r}$ と同程度の 值であり, 座屈前変形による面外変位の増幅は非常に小さいことが わかる。

6. 設計用偏心曲げモーメント $M^{r}{ }^{r}{ }_{e c} N_{y}$

\section{1 接合部の座屈耐力式}

$\mathrm{BRB}$ の座屈拘束材端部曲げ耐力を 0 とした場合の座屈荷重 $N^{{ }^{r}}{ }^{r}$ について検討する。 $N^{r}{ }^{r}$ は図 17 に示すように, $M^{r}{ }_{p}=0$ のときの接合 部座屈荷重である。式(2)で示した等価細長比 $\lambda_{r}$ を接合部断面積 $A_{2}$ と塑性化部の断面積 $A_{0}$ の比 $A_{2} / A_{0}$, 座屈長さ比 $\ell_{k 0}$ を用いて整理する と以下となる。

$$
\lambda_{r}=2 \pi \xi \cdot \ell_{k 0} \sqrt{\frac{1}{\gamma} \cdot \frac{A_{2}}{A_{0}} \frac{E}{1.5 \cdot \sigma_{y \max }} \cdot \frac{\xi \kappa_{R g}+24 / \pi^{2}}{(1-2 \xi)_{\xi} \kappa_{R g}}}
$$

さらに， $\lambda_{r}$ を用いて日本建築学会鋼構造設計規準 ${ }^{16)}$ で算出した圧縮 許容応力度 $f_{c}^{r}$ と $A_{2} / A_{0}$ を使って $N^{r}{ }_{c r}$ を を BRB の降伏軸力 $N_{y}$ で基準化 した值を表すと次式となる。

$$
N_{c r}^{r} / N_{y}=1.5 \cdot f_{c}^{r} / \sigma_{y} \cdot A_{2} / A_{0}
$$

\section{2 接合部座屈荷重 $N^{r}{ }_{c r} / N_{y}$ の評価}

表 2 の評価用特性值を用いた場合と, 標準部材(case1, case2) 各々 の特性値を用いた場合の接合部座屈荷重 $N^{r}{ }_{c r}$ および等価細長比 $\lambda_{r}$ と 接合部長さ比 $\xi$ の関係を図 18 に示す。グラフには $N^{r}{ }_{c r} / N_{y}=1.3$ のと

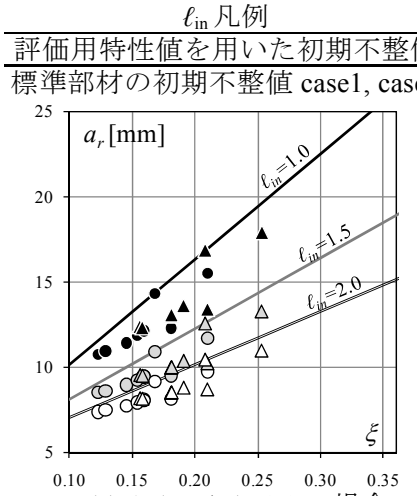

(a) $\ell_{k 0}\left(=L_{0} / L_{k}\right)=1.0$ の場合

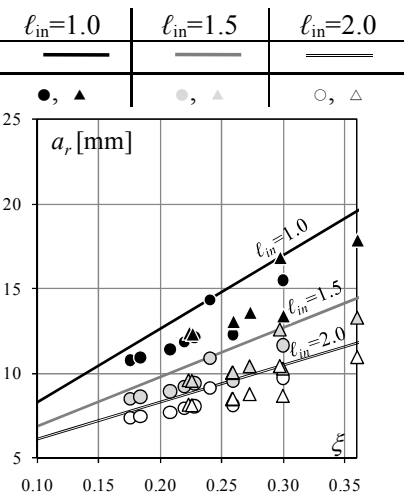

(b) $\ell_{k 0}\left(=L_{0} / L_{k}\right)=0.7$ の場合
図 15 初期不整值 $a_{r}$ と接合部長さ比 $\xi$

\begin{tabular}{c|c|c}
$N_{c r}{ }^{B}$ 凡例 & $N_{c r}{ }^{B}=N_{c r}{ }^{B s}$ & $N_{c r}{ }^{B}=N_{c r}{ }^{B m 2}$ \\
\hline 評価用特性值を用いた座屈拘束材端部の変位 & & - \\
\hline $\begin{array}{c}\text { 標準部材の座屈荷重座屈拘束材端部の変位 } \\
\text { (case1, case2) }\end{array}$ & & $\circ, \Delta$
\end{tabular}

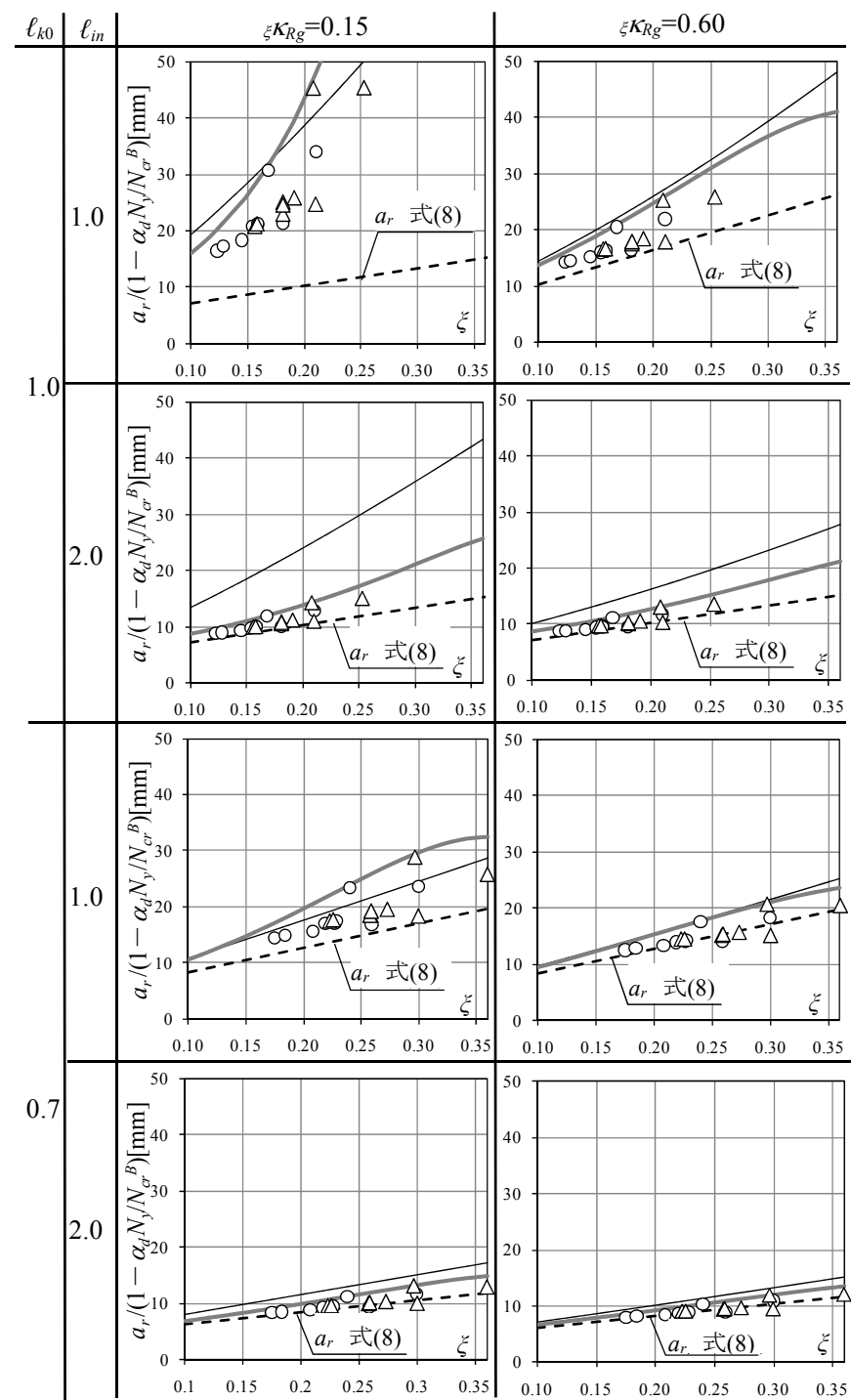

図 16 設計荷重時の座屈拘束材端部の変位

きの $\xi を$ 点線で示している。これは設計用軸力 $N_{c u}=1.3 N_{y}$ とした場合, 接合部座屈荷重が設計用軸力以上確保できる $\xi の$ 範囲を示す。評価 用特性值を用いた接合部座屈荷重は標準部材各々の特性值を用いた 
值の下限を抑えており，安全側の評価となっている。

\section{3 BRB の芯材突出部に生じる偏心曲げモーメント $M^{r^{r}}{ }^{r} / N_{y}$ の評価}

降伏軸力で基準化された機構安定条件式(4)の右辺第一項の設計 用偏心曲げモーメント $M^{r^{r}}{ }_{e c} / N_{y}$ に注目する。

図 16 と図 18 の結果を用いて $M^{r}{ }_{e d} d N_{y}$ と接合部長さ比 $\xi$ との関係を 図 19 に示寸。なお, $N^{r}{ }_{c r} / N_{y}>\alpha_{d}(=1.3)$ の場合は $M^{r}{ }_{e c} / N_{y}=0$ とした。評 価用特性值は接合部座屈荷重算定時と同様と寸る。評価用特性值を 用いて算出した值は, 標準部材各々の特性值を用いて算出した值の 上限を包括しており安全側の評価となっている。

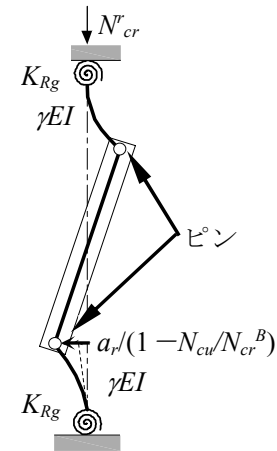

図 17 接合部座屈荷重のモデル図

\section{7. 設計用付加曲げモーメント $M^{r} / N_{y}$}

図 20 に示すように BRB が構面外層間変形により構面外方向に強 制変位 $\delta_{0}$ を受ける場合, 拘束材端部に加わる曲げモーメント $M^{r_{0}}$ を 7 要素モデル各部位の変形の和から誘導すると, 次式で表すことが できる。

$$
\begin{aligned}
\frac{M_{0}^{r}}{N_{c r}^{B 0}}= & \frac{1}{\pi^{2}}(1-2 \xi)\left\{\delta_{0}-2 s_{r}(1-2 \xi) \frac{\ell_{k 0} \cdot \ell_{w k}}{\ell_{i n}}\right\} \cdot\left(\frac{1}{\ell_{k 0}}\right)^{2} \\
& \cdot \frac{6 \gamma}{2 \xi^{\prime}\left(3-6 \xi^{\prime}+4 \xi^{\prime 2}\right)+\gamma\left(1-2 \xi^{\prime}\right)^{3}+\frac{6 \xi}{{ }_{\xi} \kappa_{R g}}+\frac{6 \gamma\left(1-2 \xi^{\prime}\right)^{2}}{{ }_{L} \kappa_{R r}}}
\end{aligned}
$$

ここで， $L_{0}$ はブレース長さ， $L_{k}$ は限界座屈長さ， $W_{1}$ は芯材突出部幅 であり, 無次元化パラメータはそれぞれ $\ell_{k 0}=L_{0} / L_{k}, \ell_{w k}=L_{k} / W_{1}$, $\ell_{i n}=L_{i n} / W_{1}$ である。一方, 既往の研究 ${ }^{13)-15)}$ では, 接合部の回転剛性に 対して拘束材の曲价剛性, 拘束材端部の回転剛性が十分に大きい場 合を想定し，式(13)が提案されている。

$$
M_{0}^{r}=(1-2 \xi)\left\{\frac{\delta_{0}}{L_{0}}-(1-2 \xi) \frac{2 s_{r}}{L_{i n}}\right\} \cdot K_{R g}
$$

式(13)の $K_{R g}$ を無次元化回転ば㸚剛性比で表現し, 限界座屈長さ $L_{k}$ に対する両端ピンの座屈荷重 $N_{c r}{ }^{B 0}$ で除すと次式となる。

$$
\frac{M_{0}^{r}}{N_{c r}^{B 0}}=\frac{1}{\pi^{2}}(1-2 \xi)\left\{\delta_{0}-2 s_{r}(1-2 \xi) \frac{\ell_{k 0} \cdot \ell_{w k}}{\ell_{i n}}\right\} \cdot\left(\frac{1}{\ell_{k 0}}\right)^{2} \cdot \frac{\xi \kappa_{R g}}{\xi}
$$

式(12)を $\gamma=1.0, L \kappa_{R r} \rightarrow \infty, E I \rightarrow \infty$ とすれば最終項は ${ }_{5} \kappa_{R g} / \xi$ となり, 式 (14) と一致する(付録 1 参照)。式(12)，(14)の $2 s_{r}(1-2 \xi) \ell_{k 0} \ell_{w k} / \ell_{i n}$ は 拘束材端部のクリアランスにより生じる変形であり, この項が小さ いほど曲げモーメントは大きくなるため, 強制構面外変形による曲 げモーメントを検討する場合には $\ell_{w k}$ を最小の 22 として評価する。 尚, 式(12)，(14)は両端ピンのオイラー座屈荷重で除しているが, ここでは式(15)のように降伏軸力 $N_{y}$ で基準化した設計用付加曲げモ 一メント $M^{r_{0}} / N_{y}$ を算出する。
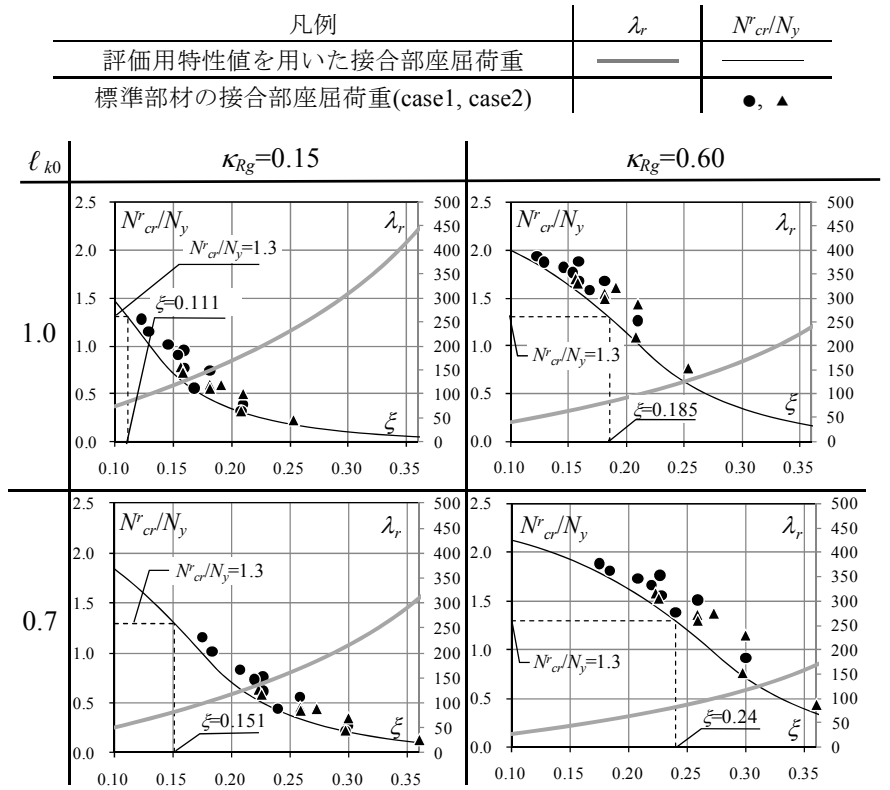

図 18 接合部の等価細長比 $\lambda_{r}$ と基準化された接合部座屈荷重 $N^{r}{ }_{r} / N_{y}$
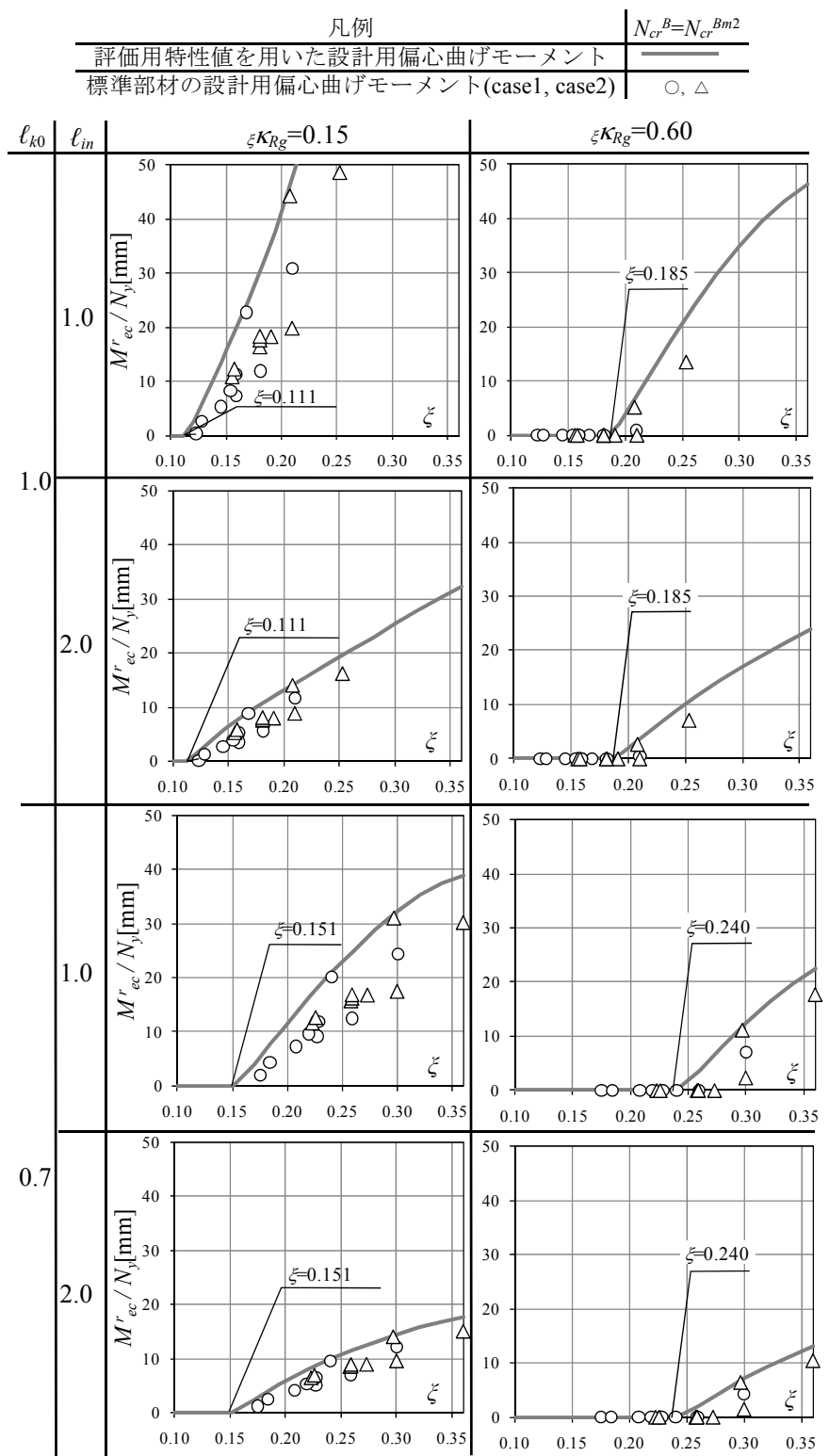

図 19 BRB の設計用偏心曲げモーメント $M^{r}{ }^{r}{ }_{e c} / N_{y}$ 


$$
M_{0}^{r} / N_{y}=M_{0}^{r} / N_{c r}^{B 0} \cdot 1.5 \cdot 245 / 225,\left(N_{c r}^{B 0}=1.5 \cdot 245 / 225 \cdot N_{y}\right)
$$

面外変位としては階高 $4500 \mathrm{~mm}$, 層間変形角 $1 / 100$ に相当する $\delta_{0}=45 \mathrm{~mm}$ を仮定し, 強制変位による付加曲げモーメントの評価を行 う。接合部曲げ剛性比 $\gamma$, 拘束材端部の回転ば社剛性比 ${ }_{L} \kappa_{R r}$ の評価用 特性值は, 安全側の評価となるように, 表 2 に示寸分布範囲中の最 大值を採用した。 $M^{r}{ }_{0} / N_{y}$ の分布は図 20 に示すように端部ほど大きく なる逆対称形であるため, 式(12), (14) ともに $\xi$ が大きくなると $M^{r_{0}} / N_{y}$ は小さくなる。

表 2 の評価用特性值による式(12)および式(14)を用いた設計用付 加曲げモーメント $M^{r}{ }_{0} / N_{y}$ を図 21 に示す。図 21 の式(12)の值は個々 の標準部材の值を包絡した結果となっており, BRB の機構安定条件 確認のための設計用付加曲げモーメントとしては, 表 2 に示寸評価 用特性値による式(12)を用いて算出した值を採用する。

\section{BRB 機構安定性の評価手法}

\section{1 芯材突出部の設計用曲げモーメント $M^{r} / N_{y}$}

評価用特性值による 6 章の設計用偏心曲げモーメント $M^{r}{ }_{e c} / N_{y}$ と 7 章の設計用付加曲げモーメント $M^{r}{ }_{0} / N_{y}$ の単純和を設計用曲げモーメ ント $M^{r} / N_{y}$ とする。

$$
M^{r} / N_{y}=M^{r}{ }_{e c} / N_{y}+M^{r_{0}} / N_{y}
$$

前章までと同様に, 表 2 の評価用特性值を用いた場合と, 標準部 材(case1, case2)個々の特性值を用いた場合の比較を行う。図 22 に設 計用曲げモーメント $M^{r} / N_{y}$, 設計用付加曲げモーメント $M^{r_{0}} / N_{y}$ を示 す。図 22 の $_{\xi} \kappa_{R g}=0.60, \ell_{k 0}=1.0, \ell_{i n}=2.0$ のグラフ中に示すように, 実 線 $\left(M^{r} / N_{y}\right)$ との点線 $\left(M^{r}{ }_{0} / N_{y}\right)$ の差が設計用偏心曲げモーメント $M^{r}{ }^{r}{ }_{e c} / N_{y}$ となる。また, $N_{c u}<N^{r}{ }_{c r}$ となる $\xi の$ 範囲を示す。この範囲は芯材突出 部の曲げモーメントの大きさに関わらず機構安定性を満足し, 設計 用偏心曲げモーメント $M^{r}{ }_{e c}$ は 0 となる。評価用特性值を用いた設計 用曲げモーメントは, 標準部材個々の特性值から算出した值よりも やや高い值となるが，す心゙てを包絡した評価となっている。

\section{2 拘束材端部の曲げ耐力 $M^{r}{ }_{p}$}

座屈拘束材端部の貫入長比 $\ell_{i n}\left(=L_{i n} / W_{1}\right) \geq 1.5 \sim 2.0$ とすれば, 座屈拘 束材端部の曲げ耐力 $M_{p}^{r-\text { rest }}$ は, 芯材突出部の曲げ耐力 $M_{p}^{r-\text { neck } よ り も ~}$ 概ね大きくなることが確認されている ${ }^{12)}$ た, 本章では芯材突出部 の曲げ耐力 $M_{p}^{r \text {-neck }}$ について検討する。 $M_{p}^{r \text {-neck }}$ は既往の研究 ${ }^{12), 13) に よ ~}$ れば式(17)で算出でき，実験值とも良い対応を示している。

$$
M_{p}^{r}=M_{p}^{r-n e c k}=Z_{p}^{r} \sigma_{y}\left\{1-\left(\frac{N_{c u}-N_{w y}^{c}}{N_{u}^{c}-N_{w y}^{c}}\right)^{2}\right\}
$$

ここで, $N^{c}{ }_{w y}$ : ウェブの降伏軸力, $N_{u}^{c}$ : 芯材突出部の終局耐力 $\left(=A_{1} \sigma_{u}\right)$, $Z_{p}^{r}$ : 芯材突出部の塑性断面係数である。 $A_{1} / A_{0}$ の評価用特性值を表 2 に示寸通り 1.33 , 芯材材質 LYP225 に対し引張強さと降伏応力度の 比 $\sigma_{u} / \sigma_{y}$ を $300 / 225=1.33$, 簡単のためウェブの降伏軸力 $N^{c}{ }_{w y}=0.5 A_{1} \sigma_{y}$ とすると $N_{y}$ で基準化された $M_{p}{ }^{r}$ は以下のように整理できる。

$$
\frac{M_{p}^{r}}{N_{y}}=\frac{Z_{p}^{r} \sigma_{y}}{N_{y}}\left\{1-\left(\frac{\alpha_{d}-0.5 A_{1} / A_{0}}{A_{1} / A_{0} \cdot \sigma_{u} / \sigma_{y}-0.5 A_{1} / A_{0}}\right)^{2}\right\}=0.67 \frac{Z_{p}^{r}}{A_{0}}
$$

\section{3 面外座屈安定性能曲線}

図 23 に図 22 の $M^{r} / N_{y}$ の実線部分のみを取り出し, 式(18)から算

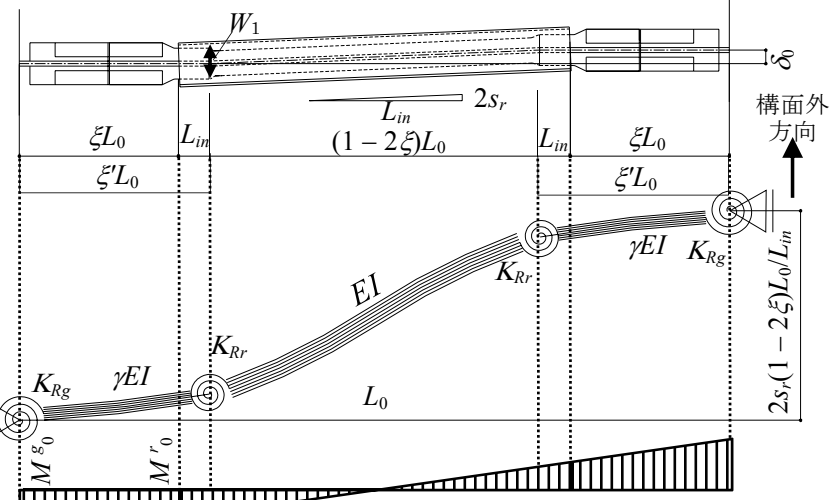

図 20 強制面外変形下の曲げモーメント分布

\begin{tabular}{c|c|c} 
凡例 & 式(12) & 式(14) \\
\hline 評価用特性值を用いた設計用付加曲げモーメント & - & - \\
\hline 標準部材の設計用付加曲げモーメント(case1, case2) & $\bullet, ~$ &
\end{tabular}

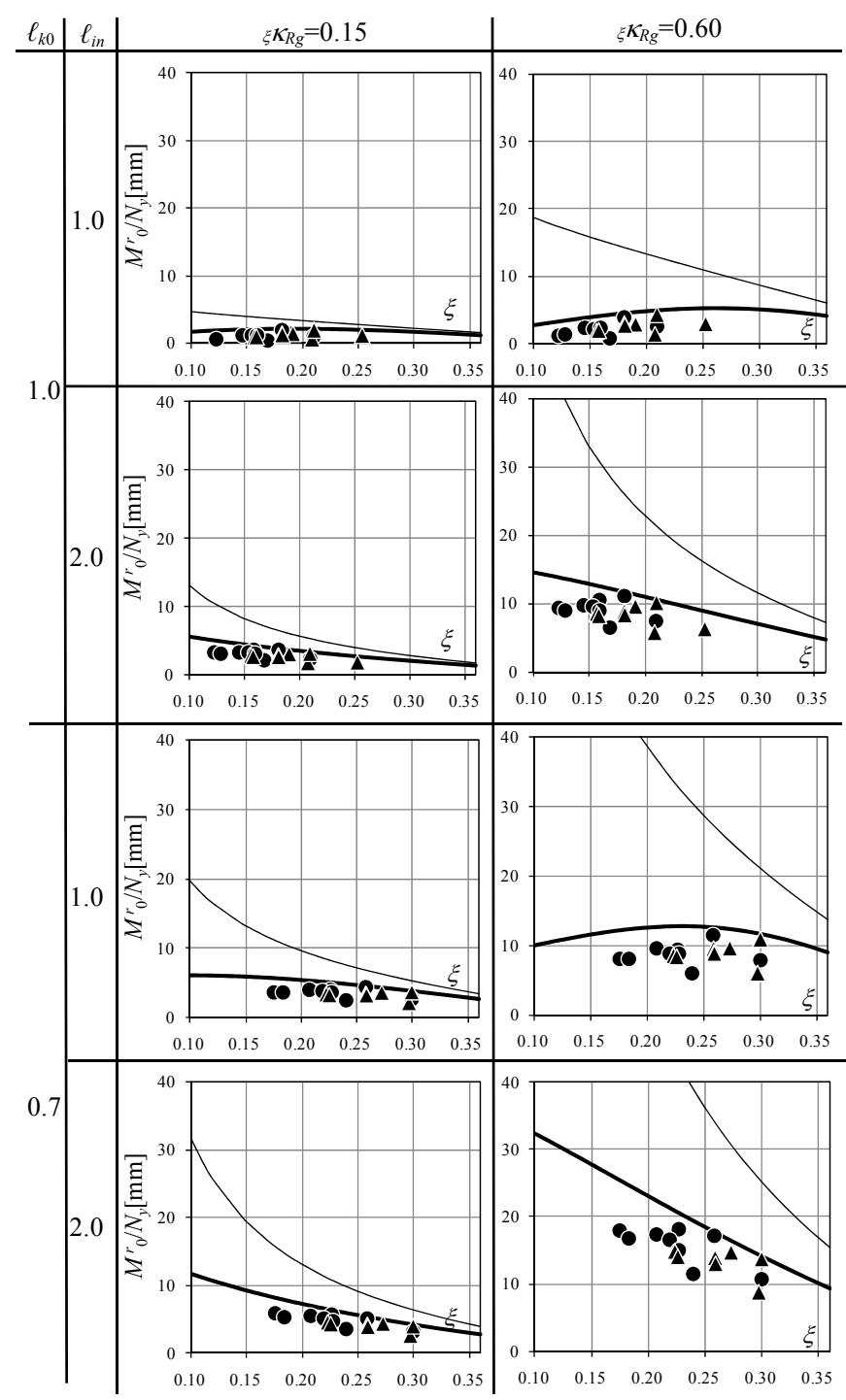

図 21 各モデルの設計用付加曲げモーメント $M^{r_{0}} / N_{y}$

出される標準部材の $N_{y}$ ごとの拘束材端部の曲げ耐力 $M_{p}{ }^{r} / N_{y}$ との比較 を示す。尚, $M^{r} / N_{y}$ については接合部が中間の剛性である $\xi_{k g}=0.3$ と 
貫入長比 $\ell_{i n}=1.5$ の場合も併せて示している。これを面外座屈安定性 能曲線と呼ぶこととする。図 23 の設計用曲げモーメント $M^{r} / N_{y}$ は $N_{y}$ に依らずに一つのグラフに表現できるため, ブレース容量によら ず設計変数特性值 $\xi, \quad \ell_{i n}, \xi \kappa_{R g}$ の機構安定性一の影響を視覚的に把握 することができる。設計時において $\ell_{k 0}=0.7 \sim 1.0$ の場合には $\ell_{k 0}=1.0$ のグラフを, $\ell_{k 0} \leq 0.7$ の場合には $\ell_{k 0}=0.7$ を使うものとする。芯材突 出部の設計用曲げモーメント $M^{r} / N_{y}$ は設計変数特性值 $\xi, \quad \ell_{i n}, \quad \xi K_{R g}$ から, 芯材突出部の曲げ耐力 $M_{p}^{r} / N_{y}$ は BRB の $N_{y}$ から, それぞれグ ラフから読み取り, $M_{p}{ }^{r} / N_{y}>M^{r} / N_{y}$ であれば面外座屈安定条件を満足 することを示す。例えば $\ell_{k 0}=1.0, N_{y}=2000 \mathrm{kN}, \xi=0.20,{ }_{\xi} \kappa_{R g}=0.15, \ell_{i n}=1.0$ の場合, 設計用曲げモーメント $M^{r} / N_{y}$ は図 23 中の $\mathrm{A}$ 点の值となり, 芯材突出部の曲げ耐力 $M_{p}{ }^{r} / N_{y}\left(N_{y}=2000 \mathrm{kN}\right.$ の線 $)$ より大きく, 安定条 件を満足していないことになる。の場合, 貫入長を長くして $\ell_{i n}=2.0$ とする(同 B 点), あるいは接合部にリブ等を配置して接合部の面外 回転剛性を高めて ${ }_{\xi} K_{R g}=0.60$ とする(同 $\mathrm{C}$ 点), または超高力ボルトの 採用等により接合部長さを短くして $=0.15$ とする(同 D 点)等により, 安定条件を満足させる $\left(M_{p}{ }^{r} / N_{y}>M^{r} / N_{y}\right)$ ことが可能となる。

尚, 面外座屈安定性能曲線において, ${ }_{\xi} \kappa_{R g}$ が大きいと $M^{r} / N_{y}$ が 0 か ら立ち上がる $\xi$ 值が大きくなる。これは, $N^{r}{ }_{c r}{ }{ }{ }_{\xi} \kappa_{R g}$ に依存して大き くなるためであり, 接合部の剛性と耐力を高めてBRBの安定性を確 保する設計法に対応している。一方, 表 1 にブレース容量の異なる 新たな BRB の部材リストを追加する場合でも, 評価用特性值の值が 表 2 の範囲内であれば, 図 23 の $M^{r} / N_{y}$ は汎用的に使うことができる 点がこの安定性能曲線の利点である。

\section{4 評価用特性値による評価の精度}

評価用特性值を用いることで $M^{r} / N_{y}$ をどの程度の誤差で評価して いるかを検討する。図 24 は, 横軸に評価用特性值による $M^{r} / N_{y}$ の評 価値を, 縦軸に標準部材個々の特性值による $M^{r} / N_{y}$ の評価値を示し ている。また, 表 5 には(評価精度) $=($ 標準部材個々の特性值による $M^{r} / N_{y}$ ) / ( 評価用特性值による $M^{r} / N_{y}$ ) として計算した評価精度の平均 值と標準偏差を示す。評価用特性值を使うことで $M^{r} / N_{y}$ をやや過大 に評価する傾向にあるものの, 既往の研究 ${ }^{13}$ において式(1)が安全側 に $30 \%$, 危険側に $15 \%$ 程度の精度で実験結果と整合していると報告 されていることを考慮すれば, 概ね安全側で機構安定性を評価でき ていると考える。

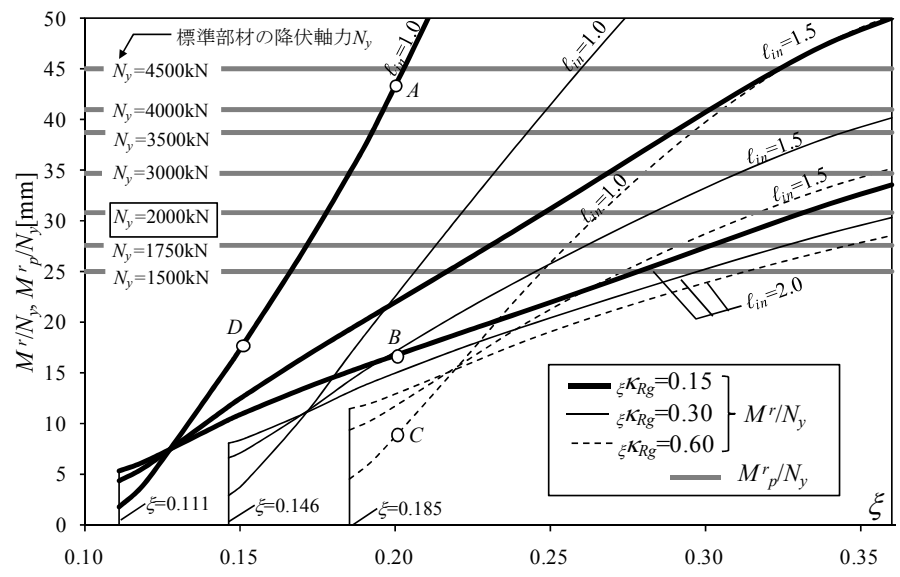

(a) $\ell_{k 0}=1.0$ の場合

\begin{tabular}{c|c|c} 
凡例 & $M^{r} / N_{y}$ & $M^{r} / N_{y}$ \\
\hline 評価用特性值を用いた設計用曲げモーメント & - & ---- \\
\hline 標準部材の設計用曲げモーメント(case1, case2) & $\bullet, . ~$ &
\end{tabular}

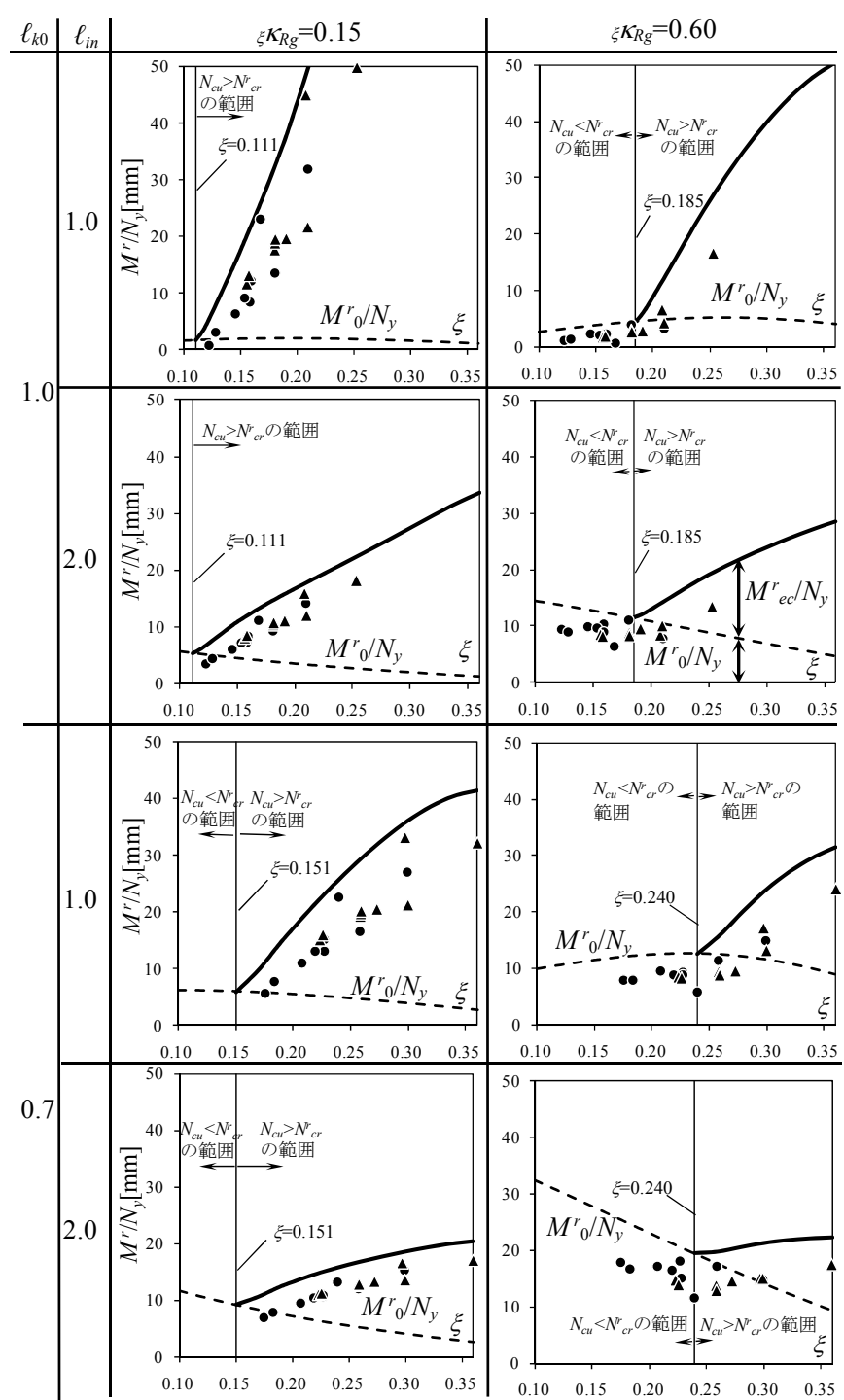

図 22 芯材突出部の設計用曲げモーメント

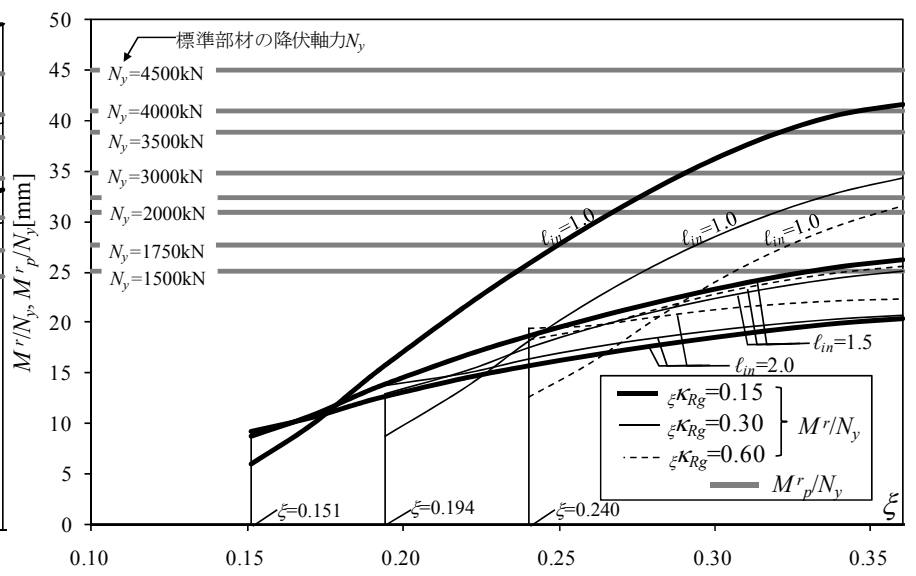

(b) $\ell_{k 0}=0.7$ の場合

図 23 BRB の面外座屈安定性能曲線 (LYP225 芯材形状+タイプ) 


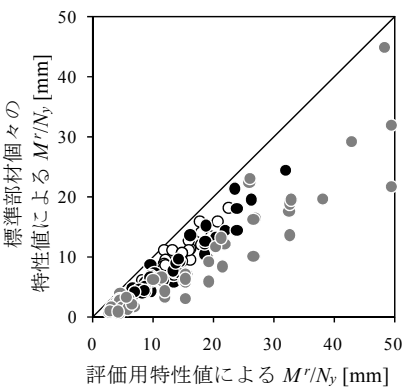

(a) $\ell_{k 0}=1.0$ の場合

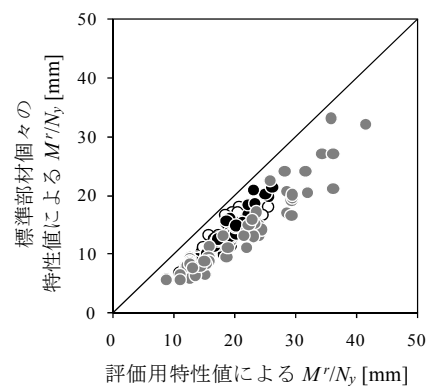

(b) $\ell_{k} 0=0.7$ の場合
図 24 本検討範囲における $M_{p}^{r} / N_{y}$ の精度

表 5 評価用特性値を使うことによる評価精度

\begin{tabular}{|c|c|c|c|c|}
\hline Mark & $\ell_{k 0}$ & $\ell_{i n}$ & 平均值 & 標準偏差 \\
\hline 0 & \multirow{3}{*}{1.0} & 2.0 & 0.68 & 0.068 \\
\hline - & & 1.5 & 0.63 & 0.112 \\
\hline 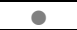 & & 1.0 & 0.50 & 0.176 \\
\hline 0 & \multirow{3}{*}{0.7} & 2.0 & 0.73 & 0.065 \\
\hline$\bullet$ & & 1.5 & 0.70 & 0.072 \\
\hline - & & 1.0 & 0.64 & 0.010 \\
\hline
\end{tabular}

9. 結

本研究では, 実際の建物に用いられている BRB および接合部ディ テールを調查・分析し, 既往の研究で提案された BRB の機構安定条 件式中の各項の值に寄与する各種特性值を特定すると共に, BRB の 機構安定性を視覚的に評価できる手法を提案した。以下に得られた 知見を示す。

1) 実際に用いられている接合部ディテールの FEM 解析により, 接 合部端部の構面外回転剛性を評価した結果, 取付く柱梁の剛性 の影響が大きく, 面外変形を拘束するためのリブを設けた場合 においても, 接合部端部が柱梁と剛に接合された場合の回転剛 性の半分程度以下となる場合があり, 特に剛な接合部を評価す る場合は, 柱梁を含めた接合部の構面外回転剛性の影響を考慮 する必要がある。

2) 実際使われている BRB や接合部ディテールを調查・分析し, 機 構安定条件式の各項に寄与寸る特性值の内, 主要な変動パラメ 一タとしての設計変数特性值と一定值として取り扱える評価用 特性值を特定した。また, 設定した評価用特性値は, 実際に多 く用いられているBRBの機構安定性を安全側に評価できている ことが確認された。

3)これらの特性值を用いて算定した拘束材端部位置での単位降伏 軸力あたりの設計用曲げモーメントと, 単位降伏軸力あたりの 拘束材端部の曲げ耐力の大小関係を面外座屈安定性能曲線上で 比較することにより, 既往の研究で提案された BRB の機構安定 条件を条件式に数值を代入することなく視覚的に評価できるこ とを示した。

今後は BRB の片側が梁に取付く $\mathrm{K}$ 型配置, または接合部が塑性 化した場合の機構安定条件の要因を分析し, さらに, 接合部の構面 外剛性評価において FEM 解析を都度行うことは実務設計上現実的 ではないので，より簡便な評価方法を検討していく予定である。

\section{謝辞}

本研究を進めるにあたり, 新日鉄住金エンジニアリング : 市川康 氏, 樋口公平氏, 帆足勇磨氏, 日建設計 : 木村征也氏, 井田茉利氏, 大山翔也氏にご協力を頂きました。ここに深謝いたします。
参考文献

1) 井上一朗 : 鋼構造制振技術の現状と設計指針への期待 -鋼構造における 制振とこれから- (2)座屈拘束ブレースと接合部, 2006 年度日本建築学会 大会(構造部門(鋼構造))パネルディスカッション資料, pp.8-17, 2006.9

2) 天香秀秋, 聲高裕治, 井上一朗 : 接合部を含む座屈拘束ブレースの構面 外座屈荷重, 日本建築学会構造系論文集, 第 581 号, pp.127-134，2004.7

3) 木下智裕, 聲高裕治, 井上一朗, 飯谷邦祐 : 接合部を含む座屈拘束ブレ 一スの構面外座屈防止条件, 日本建築学会構造系論文集, 第 621 号, pp.141-148, 2007.11

4) 藤井俊二, 田川浩 : 丸鋼芯材を二重鋼管により座屈拘束したブレースの 挙動特性, 日本建築学会構造系論文集, 第 659 号, pp.167-174, 2011.1

5) 木下智裕, 聲高裕治, 井上一朗, 飯谷 邦祐 : 十字形断面をもつ座屈拘束ブ レース接合部の構面外曲げ剛性と降伏曲げ耐力, 日本建築学会構造系論 文集，第 632 号，pp.1865-1873，2008.10

6) Chou, C. C., Chen, P. J. : Compressive behavior of central gusset plate connections for a buckling-restrained braced frame, Journal of Constructional Steel Research, No. 65, pp.1138-1148, 2009

7) Tsuyoshi Hikino, Taichiro Okazaki, Koichi Kajiwara and Masayoshi Nakashima : Out-of-plane Stability of Buckling-Restrained Braces Placed in Chevron Arrangement, Journal of Structural Engineering, ASCE, Vol. 139, pp.1812-1822, 2013.11

8) Junxian Zhao, Bin Wu and Jinping Qu : A practical and unified global stability design method of buckling-restrained braces, Discussion on pinned connections, Journal of Constructional Steel Research, Vol. 95, pp.106-115, 2014.4

9) Chou, C. C., S. Y. Chen : Subassemblage tests and finite element analyses of sandwiched buckling-restrained braces, Engineering Structures, Vol. 32, pp.2108-2121, 2010.8

10) 日本建築学会 : 鋼構造座屈設計指針, 3 章 筋かい材, 2009.11

11）竹内 徹, 山田哲, 北川まどか, 鈴木一弁, 和田章 : 構面外剛性の低い 接合部により接合された座屈拘束ブレースの座屈安定性, 日本建築学会 構造系論文集，第 575 号，pp.121-128，2004.1

12) 竹内 徹, 松井良太, 西本晃治, 高橋聡史, 大山翔也 : 拘束材回転剛性 を考慮した座屈拘束ブレースの有効座屈長, 日本建築学会構造系論文集, 第 639 号, pp.925-934, 2009.5

13) 竹内徹, 小㠃均, 松井良太 : 拘束材端部の曲げモーメント伝達能力を考 慮した座屈拘束ブレースの構面外機構安定性評価, 日本建築学会構造系 論文集，第 78 巻，第 691 号, pp.1621-1630, 2013.9

14) Toru Takeuchi, Hitoshi Ozaki, Ryota Matsui, Fatih Sutcu: Out-of-plane stability of buckling-restrained braces including moment transfer capacity, Earthquake Engineering of Structural Dynamics, doi: 10.1002/eqe.2376, 2013

15) 日本建築学会 : 鋼構造の座屈に関する諸問題 2013, 2. 接合部を含む座屈 拘束ブレースの構面外安定条件, 2013.6

16) 日本建築学会 : 鋼構造設計規準一許容応力度設計法一, 2005.9

17）新日鉄住金エンジニアリング株式会社：アンボンドブレース技術資料

付録 1

式(12)にて接合部の回転変形以外を無視した場合について以下に示す。 式(12)の $\gamma \rightarrow 1,1 /_{L} \kappa_{R r} \rightarrow 0$ とすると以下となる。

$M_{0}^{r}=\frac{1}{\pi^{2}}(1-2 \xi)\left\{\delta_{0}-2 s_{r}(1-2 \xi) \frac{L_{0}}{L_{i n}}\right\} \cdot\left(\frac{L_{k}}{L_{0}}\right)^{2} \cdot \frac{6}{1+\frac{6 \xi}{\xi} \kappa_{R g}} N_{c r}^{B 0}$

$=\frac{1}{\pi^{2}}(1-2 \xi)\left\{\delta_{0}-2 s_{r}(1-2 \xi) \frac{L_{0}}{L_{i n}}\right\} \cdot\left(\frac{L_{k}}{L_{0}}\right)^{2} \cdot \frac{6}{1+\frac{6 \xi}{K_{R g} \cdot \frac{\xi L_{0}}{\gamma E I}}} N_{c r}^{B 0}$

$=\frac{1}{\pi^{2}}(1-2 \xi)\left\{\delta_{0}-2 s_{r}(1-2 \xi) \frac{L_{0}}{L_{i n}}\right\} \cdot\left(\frac{L_{k}}{L_{0}}\right)^{2} \cdot \frac{6}{1+\frac{6 \xi}{K_{R g} \cdot \frac{\xi L_{0}}{\gamma E I}}} \frac{\pi^{2} E I}{L_{k}^{2}}$

$=(1-2 \xi)\left\{\delta_{0}-2 s_{r}(1-2 \xi) \frac{1}{L_{i n}}\right\} \cdot \frac{1}{\frac{L_{0}}{6 E I}+\frac{1}{K_{R g}}}$

式(付 1)には鋼管の曲げ剛性が含まれているため, $1 / E I \rightarrow 0$ とすると本文式(13) と同じであり，無次元化パラメータを使って表現すると式(14)となる。 


\title{
OUT-OF-PLANE STABILITY FACTORS FOR DIAGONALLY INSTALLED \\ BUCKLING RESTRAINED BRACES
}

\author{
Hitoshi OZAKI ${ }^{* 1}$, Yoshinao KONISHI ${ }^{* 2}$, Ryota MATSUI*3 \\ and Toru TAKEUCHI*4 \\ * 1 Nikken Housing System Ltd., M. Eng. \\ *2 Nippon Steel \& Sumikin Engineering Co., Ltd., Dr. Eng. \\ ${ }^{*} 3$ Assist. Prof., Dept. of Arch. and Build. Eng., Tokyo Institute of Technology, Dr. Eng. \\ ${ }^{*}{ }^{4}$ Prof., Dept. of Arch. and Build. Eng., Tokyo Institute of Technology, Dr. Eng.
}

\section{Introduction}

Series of formula for securing the out-of-plane stability of buckling restrained brace (BRB) have been proposed in previous studies. However, the actual ranges of each index that make up this series of formula are not clarified for practical engineers. In this paper, these are divided into two indices called a design index and an evaluated index, and their actual values are determined by carrying out the research studies of various BRBs and their connections that are used in the actual buildings. Based on these results, a simple method that can evaluate the out-of-plane stability condition of the BRBs with various connection conditions is proposed.

\section{BRB Index}

The four indices mainly governing the mechanical stability condition for BRBs are selected as the design index, and five indices remaining in a certain range are selected as the evaluated index. The evaluated index is determined to keep the safety margin of the mechanical stability condition.

\section{Investigation of the range of the design index}

The range of the design index is investigated on the basis of the configuration for the practical design examples. The range of the design index for the connection rotational stiffness is determined by the FEM analysis results of the column-beam connection in typical office buildings that stand around 100 meters.

\section{Evaluation of Global Elastic Buckling Strength of BRB}

According to the previous studies, a seven-element-model composed by two rotational springs of gusset plate, two rotational springs of restrainer ends and three elastic bending elements is used to assess the global elastic buckling strength of BRB.

\section{Out-of-plane Displacement at Restrainer Ends under Design Axial Force}

Total initial imperfection and incremental value of the out-of-plane displacement at restrainer ends under design axial force are determined.

\section{Eccentric Bending Moment Requirements Considering Rotational Spring Stiffness at Gusset Plate}

From the value of the global elastic buckling strength with pin supports at restrainer ends and the out-of-plane displacement which are estimated in the previous section, eccentric bending moment requirements considering rotational spring stiffness at gusset plate is defined.

\section{Additional Bending Moment Requirements under Out-of-plane Drift}

A standard for out-of-plane displacement equivalent to $1 \%$ radian story drift is verified for additional bending moment requirements.

\section{Evaluation of Out-of-plane Stability Condition of BRBs}

A method to determine the out-of-plane stability of the BRBs by comparing moment transfer capacity with bending moment requirements at restrainer ends is proposed. Some examples of the out-of-plane stability evaluation method are demonstrated by using a diagram visually without a complicated calculation.

\section{Conclusion}

As a conclusion, the following results are obtained.

1) FEM analysis results on the connections of the BRBs give that the out-of-plane rotational stiffness of their ends is significantly dominated by the column and beam. The rotational stiffness of the model with the elastic column and beam is less than half of that with the rigid column and beam. It is noted that the stiffness of the column and beam should be taken into account in practical design.

2) The standards for the items in the formula series of the BRB out-of-plane stability conditions are summarized respectively by the numerical simulations of the practical design models.

3) Based on these result, it is shown that the out-of-plane stability condition of BRBs with various connection conditions can be evaluated by comparing moment transfer capacity with bending moment requirement at restrainer ends without the complicated calculations. 